\title{
Institutionalizing Precarious Immigration Status in Canada
}

\section{Luin Goldring}

York University

\section{Carolina Berinstein}

Access Alliance Multicultural Health and Community Services

\section{Judith Bernhard}

Ryerson University

\section{digital.library.ryerson.ca/object/83}

Please Cite:

Goldring, L., Berinstein, C., \& Bernhard, J. (2007). Institutionalizing precarious immigration status in Canada. CERIS Working Paper Series, 61.

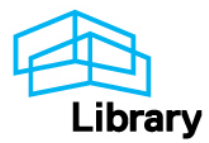




\section{WORKING PAPER SERIES}

INSTITUTIONALIZING PRECARIOUS IMMIGRATION STATUS IN CANADA

Luin Goldring,

Carolina Berinstein, and

Judith Bernhard

CERIS Working Paper No. 61

December 2007

Series Editor for 2007/08

Michael J. Doucet, PhD

Department of Geography

Ryerson University

350 Victoria Street

Toronto, Ontario

M5B 2 K3

mdoucet@ryerson.ca

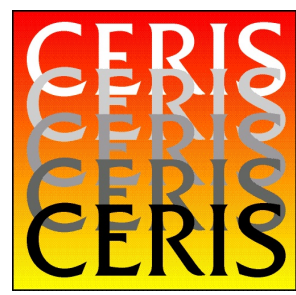

CERIS - The Ontario Metropolis Centre 
The CERIS Working Paper Series

Manuscripts on topics related to immigration, settlement, and cultural diversity in urban centres are welcome. Preference may be given to the publication of manuscripts that are the result of research projects funded through CERIS - The Ontario Metropolis Centre.

All manuscripts must be submitted in both digital and hard-copy form, and should include an Abstract of 100-200 words and a list of keywords.

If you have comments or proposals regarding the CERIS Working Paper Series please contact the Editor at:

(416) 946-3110 or e-mail at <ceris.office@utoronto.ca>

Copyright of the papers in the CERIS Working Paper Series is retained by the author(s)

The views expressed in these Working Papers are those of the author(s), and opinions on the content of the Working Papers should be communicated directly to the author(s) themselves.

CERIS - The Ontario Metropolis Centre 246 Bloor Street West, $7^{\text {th }}$ Floor, Toronto, Ontario, Canada M5S 1V4

Telephone (416) 946-3110 Facsimile (416) 971-3094 


\title{
Institutionalizing Precarious Immigration Status in Canada ${ }^{1}$
}

\author{
Luin Goldring \\ Sociology/CERLAC \\ York University \\ E-mail: goldring@yorku.ca \\ Carolina Berinstein \\ Access Alliance Multicultural Health and Community Services ${ }^{2}$ \\ E-mail: cberinstein@accessalliance.ca \\ Judith Bernhard \\ School of Early Childhood Education \\ Ryerson University \\ E-mail: bernhard@,ryerson.ca
}

\begin{abstract}
This paper presents an analysis of the institutionalized production of precarious immigration status in Canada. We build on recent work on the legal production of illegality and non-dichotomous approaches to immigrant legal status. Canadian immigration policy allows for various categories of permanent and temporary immigrants, refugees and visitors. Once in Canada, people may shift from relatively secure but largely temporary statuses to less secure statuses, including illegality. We argue that binary conceptions of legal status do not reflect the Canadian policy context, and propose the use of "precarious status" to capture the various forms of irregular status and illegality.
\end{abstract}

${ }^{1}$ An early version of this paper was presented at the 2003 Annual Conference of the Centre for Research on Latin America and the Caribbean (CERLAC) at York University (Goldring and Berinstein 2003). The paper emerged out of an academic-community collaboration between Luin Goldring, a sociologist at York University, and Carolina Berinstein, a health promoter at Access Alliance Multicultural Community Health Centre, in Toronto. Goldring's plans to study immigration status issues developed in collaboration with Patricia Landolt (University of Toronto). Subsequently, Goldring, Berinstein, and Landolt joined Judith Bernhard, of Ryerson University, and other colleagues in the academic and community sectors in developing a research proposal on "Living with Less-ThanFull Status" which was submitted to the Canadian Social Science and Humanities Research Council, under the Community-University Research Alliance (CURA) initiative. Unfortunately, the proposal did not receive funding in 2005 , or again in 2006 .

${ }^{2}$ Access Alliance works to promote health and wellbeing and improve access to services for immigrants and refugees in Toronto by addressing medical, social, economic and environmental issues. Community health centres (CHCs) were established to provide health services to individuals and communities facing barriers to accessing mainstream services. As such, CHCs provide services to non-insured persons. Non-insured persons include those who do not have provincial health insurance coverage, such as homeless individuals who may have lost their cards, or immigrants who are not eligible for coverage because of their immigration status. 
Implications of precarious status for accessing public services are also discussed. We offer five conclusions about the Canadian context: Canadian immigration policy generates precarious immigration status, including illegality. Precarious immigration status is accompanied by precarious access to public services. Pathways to precarious status are gendered and racialized. This has implications for citizenship, stratification, and exclusion in Canada. Finally, trends in immigration and refugee policy indicate that the population with precarious status is likely to grow. For people with precarious status, identifying various forms of precarious status may be less relevant than the overall precariousness of everyday life. For scholars, activists, agencies and policy-makers, analyzing the production of precariousness in specific national contexts can contribute to theorizing immigration status as an important dimension of social exclusion, and to generating better understanding of the topic.

KEY WORDS: Illegality, immigrants, legal status, precariousness, undocumented, Canada.

\section{ACKNOWLEDGMENTS}

The authors are grateful to Heather Jessome, general manager at the COSTI reception centre in Toronto, Janet Dench, of the Canadian Council for Refugees, and Rhonda Roffey, of Women's Habitat, for providing information through personal communication, and to Patricia Landolt and Julie Young for valuable comments on earlier drafts of this paper. They also acknowledge the opportunity to work with the other members of the CURA team. 


\section{Table of Contents}

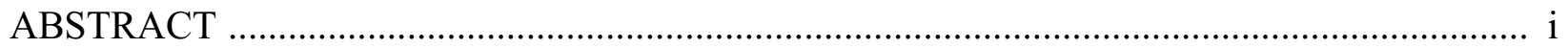

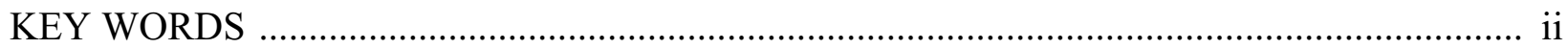

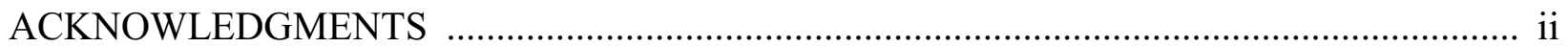

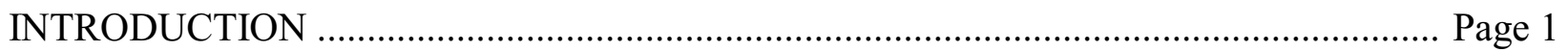

THEORIZING ILLEGALITY AND IMMIGRATION STATUS: DIFFERENT

CONTEXTS AND SCHOLARSHIP .............................................................. Page 3

The Legal Production of Illegality ........................................................................ Page 4

Producing Illegality ............................................................................... Page 5

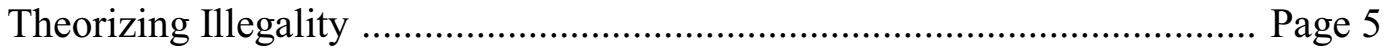

Precariousness ................................................................................. Page 6

THE PRODUCTION OF ILLEGALITY IN THE CANADIAN CONTEXT ...................... Page 7

Different Contexts, Differences in Unauthorized Entry ......................................... Page 7

Trends in Canadian Immigration Policy and Patterns ............................................ Page 9

Permanent Residents ........................................................................ Page 10

Temporary Residents ........................................................................... Page 12

PATHWAYS TO SECURE STATUS, PATHWAYS TO PRECARIOUS STATUS ....... Page 16

Family Sponsorship and Sponsorship Breakdown ............................................... Page 16

Refugee Policy and Process: Protection and Precariousness ................................ Page 17

Temporary Workers ................................................................................... Page 20

Seasonal Workers …….......................................................................... Page 20

Entertainers ..................................................................................... Page 21

Construction Workers ...................................................................... Page 21

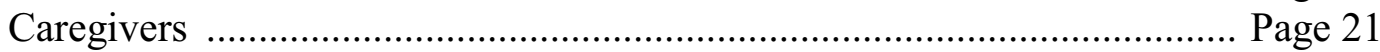

Other Temporary Residents: Visitors and Students ............................................ Page 22

Recourse after Falling Out of Status ............................................................... Page 22

Judicial Review ................................................................................. Page 22

Pre-Removal Risk Assessment (PPRA) ……….................................... Page 23

Humanitarian and Compassionate Applications ..................................... Page 23

PRECARIOUS STATUS, PRECARIOUS ACCESS TO SERVICES AND

SOCIAL EXCLUSION ………………………................................................ Page 23

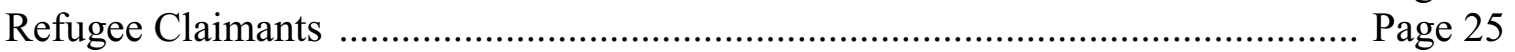

Sponsored Family Members ……................................................................ Page 25

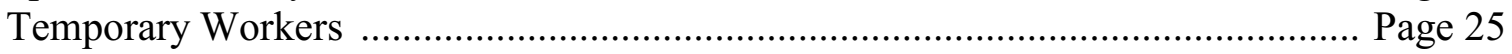

Visitors and International Students ............................................................... Page 26

Persons with No Status .............................................................................. Page 26 
Ambiguity and Precariousness in Service Delivery

Page 27

DISCUSSION

Page 28

CONCLUSIONS

Page 30

REFERENCES

Page 32 


\section{INTRODUCTION}

"Illegal," "unauthorized," "alien," "undocumented," "wet-back," "sin papeles," and "sans papiers." These are some of the terms used in North America and Europe to refer to people who cross borders without authorization, or reside and/or work without the full legal status of citizenship, or the "nearly full" status of permanent residence. In Canada, activists and academics introduced the term non-status because many in this situation are documented in the sense that they are known to the state (STATUS 2003). Each of these terms reinforces a binary categorization of immigrant and refugee legal statuses that distinguishes those with lawful legal status from those without it. The dichotomous contrast has gained currency in the context of the United States, where unauthorized border crossing is the main pathway to unlawful status. Elsewhere, however, national contexts with different modes of legal and unauthorized entry and pathways to "illegality" may call for a different vocabulary and conceptualization of immigrant legal status. ${ }^{3}$

In the United States, undocumented immigration is an extremely contentious issue, but also an undeniable feature of the society and economy. The size of the undocumented population has been estimated at about 12 million (Kiely 2007), a figure notable for its magnitude and the fact that it reflects substantial efforts and resources dedicated to gathering data and developing techniques to produce such estimates (Warren and Passel 1987; Van Hook et. al 2005). ${ }^{4}$ In contrast, in Canada, immigrant legal status is a non-issue for most Canadians. Public debate regarding immigration is more likely to touch on immigrant integration under multiculturalism, the non-recognition of foreign credentials, and, perhaps, the backlog in refugee determination. Estimates of the non-status population vary from a low of 20,000 to upwards of 500,000 (Vickery 2004; Jimenez 2006; Singh 2006), with no clear empirical basis for the figures. In recent years, specific events, such as the arrival of boats bearing "illegal" migrants or refugee claimants, deportations, or surges in refugee claims from specific countries, have received bursts of media coverage, which then dissipates. Advocacy groups are conducting campaigns in favor of regularization and "Don't Ask, Don't Tell" policies, but these do not enter mainstream agendas. The issue remains poorly understood and relatively absent from public debate and scholarship.

How should we understand the way the issue is treated in Canada? Are differences in location, geography, history, and the southern borders enough to account for variation in the terminology, size of the populations in question, and the way the issue is treated in Canada

\footnotetext{
${ }^{3}$ Following De Genova (2002), we enclose the term "illegal and "illegality" in quotes as a way of interrogating the social, administrative, legal, and political construction of the category, and questioning the uncritical use of the term as an adjective for people. We certainly agree that it is not a term that should be applied to people (as suggested in the title of the activist organization No One is Illegal), yet we do use the term for two reasons. First, because the term used by many immigration advocates in the US, "undocumented," is not always applicable in the Canadian context, and second, to underscore the production of illegality, as De Genova does, and which is one of the main purposes of this analysis.

${ }^{4}$ The 12 billion figure represented four per cent of the total US population estimate for 2007, which was 301,139,947 (CIA 2007).
} 


\section{Page 2}

compared to the United States? While these factors would be part of any reasonable response, we believe there is more to consider.

This paper examines pathways to illegality in Canada as a part of an effort to theorize the production of illegality (De Genova 2002) and precarious status in Canada. We examine immigration policy and trends, modes of entry, and pathways to insecure legal status and find that existing opportunities for legal entry combine with multiple pathways to precarious status, including no status, to produce a confusing array of gradations of uncertain or "less-than-full" immigration status, and movement between them. ${ }^{5}$ This requires a non-dichotomous approach to theorizing illegality and its connection to citizenship and rights. We propose an alternative conceptualization and use precarious legal status to describe multiple forms of irregular or "less than full" legal statuses. The discussion also suggests that the legal production of documented illegality and precariousness in Canada has contributed to the relative lack of visibility and treatment of the issue of immigrant status.

These conceptual issues have important implications for people living without full status and for service providers, activists, advocates, policy makers, and members of the broader public. Not recognizing the institutionalized production and the complexity and confusion of precarious legal status in Canada obscures the presence and plight of people living either without status or with precarious status, as well as the legal and systemic production of this category of people. Lack of visibility compounds the vulnerability and marginalization of people with precarious status and their families by reproducing an underclass that is vulnerable on several fronts, including inadequate access to health and other services, limited recourse in the event of abuse at work or other arenas, and deportation. In addition to being a problem of lived experience for people with precarious status, the invisibility of the topic makes legal status the unspoken dimension of social exclusion in Canada. Given the ways in which Canadian immigration and refugee policies operate, people with precarious status are also negatively racialized, which raises questions about the legal production of racialized illegality and legal status as a form of social exclusion.

We begin by developing a framework for analyzing the production of migrant "illegality" and precariousness, which includes a selected review of relevant literature; we use this as an argument for a closer examination of the national context in which models of illegality are produced. In the next part, we provide an overview of Canadian immigration policy and trends. This is followed by a more detailed description and analysis of modes of entry into Canada and pathways to various forms of less-than-full status. This section supports our contention that forms of precarious legal status are routinely produced through contemporary Canadian immigration policy and procedures. Next, we consider the implications of precarious status through a discussion of access to social services. This is motivated by our interest in generating discussion regarding the effects on, and implications of, this form of social exclusion for both people with precarious legal

\footnotetext{
5 The term "gradations" suggests a continuum or scale. We are not proposing that there is an ordered scale or hierarchy going from more to less, or full to no, immigration status. Rather, we use the concept to refer to various situations of less-than-full status, with people potentially moving from one "state" to another, and with different states or gradations marked by the presence or absence of one or more of the following: work permit, government health coverage, and residence permit.
} 
status and Canadian society as a whole. In the concluding section, we discuss theoretical and practical implications of the analysis.

\section{THEORIZING ILLEGALITY AND IMMIGRATION STATUS: DIFFERENT CONTEXTS AND SCHOLARSHIP}

The literature on the unauthorized, illegal, irregular, or undocumented is vast; rather than reviewing it, we briefly characterize its breadth. Early American work began with structural accounts of the role of undocumented labour (Burawoy 1976; Bustamante 1976; Portes 1978), and moved on to political economy and ethnographic studies of undocumented workers in specific sectors or settings. Bi-national community studies (Mines 1981; Massey et. al 1987) produced early multi-sited studies drawing connections between rural migrant communities in Mexico and the settlement experiences of Mexican immigrants, many of them undocumented. After developing datasets and approaches for measuring the size of the population and estimating Census undercounts (Warren and Passel 1987), quantitative analysts also addressed the labour market effects of undocumented labour in the US from various perspectives, including labour market segmentation theory and neoclassical economics. Following the 1986 Immigration Reform and Control Act, numerous studies examined the effects of this and other policies. During the 1990s, the scope of inquiry continued to broaden, with analyses of the undocumented as political actors (Delgado 1993), the everyday marginal experiences of the undocumented (Chavez 1992), and the process of becoming legal (Hagan 1994), to name only a few. Research in various disciplines has continued to address methodological and measurement problems, border enforcement, state policy, the construction of the undocumented, gender and legal status, labour markets, the economic and social "costs and benefits" of immigration, and a host of other issues. More recently, studies have interwoven the everyday experience of being without legal status with attention to broader social, economic, and political contexts (Menjívar 2000; DeGenova 2005; Zloniski 2006). The large body of work on the topic in the United States reflects the pervasiveness of the issue as well as its political and polemical nature. Whatever one's views or theoretical approach, it is a visible issue that is on the table, and one that generally does not require any discussion of the definition of "undocumented."

In Canada, the situation is different. There is a much smaller body of scholarship on the topic, distinct and sometimes confusing terminology, and no efforts to collect large-scale systematic data on or about people with confusing or no legal immigration status. As indicated earlier, estimates of the number of people without legal status in Canada have ranged considerably in the last five years, from a low of 20,000 to a recent high of 600,000 (Jimenez 2003; Robertson 2005; CBC 2006). The variability in these estimates reflects the absence of systematic academic, government, or other analyses of "the numbers" and the problem of defining the population. ${ }^{6}$ This

\footnotetext{
${ }^{6}$ Defining the population is not straightforward, as it is not always clear who fits the non-status label, should it be reserved for people with no authorization to live in Canada? What about those with authorization to reside but not work in Canada? Another problem with the term is that in Canada, it is also used in relation to
} 
Page 4

stands in contrast to the United States, where sophisticated techniques have been used over the last two decades to estimate the size of the undocumented population (Warren and Passel 1987; Van Hook 2005). At present, available social science research in Canada on the experiences of nonstatus immigrants has been limited to a few important case studies (PCLS 1998; LACEV 2002; San Martin 2004; Young 2005), and studies examining service providers and access to services for people without status (Berinstein et. al 2006; Khandor et. al 2004; CSPC-T 2007). Within this category, the issue of access to health services and health status has emerged as an important area of research (Simich 2006; Simich et. al 2007; Oxman-Martinez et. al 2005).

In spite of the absence of estimates or broader social science research, there are advocacy groups working on various aspects of immigration status in Canada. Community organizations, activists and people with irregular status have organized and lobbied for both the regularization of people without status (STATUS 2003; Khandor et. al 2004; Lowry and Nyers 2003) and "Don't Ask, Don't Tell” municipal policies (Keung 2006). In addition, mobilizations around legal status have been studied from social movements/advocacy networks perspectives (Guang and Lu 1996; Wright 2003). However, to our knowledge, there have been no analyses of the role of undocumented or less-than-full status workers in specific labour markets or industries, or studies of other aspects of legal status that would begin to parallel the extensive array of US-based studies on the undocumented. ${ }^{7}$

\section{The Legal Production of Illegality}

Part of the explanation for the situation in Canada is the way people become "illegal" in this national context. To develop a conceptual framework for analyzing this process, we pull together insights from two sub-fields of scholarship within the broader literature on illegality and the undocumented. The first draws attention to the "legal production of illegality;" the second questions dichotomous approaches to migrant legal status. Research on precarious employment rounds out our conceptual approach to precarious immigration status. Drawing on insights from these three fields is critical to our conceptualization of precarious legal status because they draw attention to the systemic, legal, and unquestioned production of a range of precarious, or less-than-full, immigration statuses.

aboriginal status: non-status refers to aboriginals who lack legal aboriginal status (according to treaties and rules governing marriage and lineage) but claim aboriginal identity.

${ }^{7}$ There is an extensive Canadian literature in the general area of labour studies that includes analyses of precarious employment, restructuring, union organizing, and related topics (Vosko 2006). There is also a growing literature on the racialization of poverty (Galabuzi 2006) and ethnoracial inequality (Ornstein 2006). While both of these areas of scholarship include attention to gender, racialization, class, and differences between native born and immigrants, they do not examine precarious legal status. It is only in work on temporary and domestic workers that we find explicit discussions of immigration status, rights, recourse or lack of recourse, wellbeing, and social exclusion (for example, Basok 2002, 2004; Preibisch 2004; San Martin 2004; Sharma 2001; Stasiulis and Bakan 1997, 2003). 


\section{Producing Illegality}

Calavita's (1998) work on immigration policy in Spain broke new ground by theorizing the production of illegality as an ongoing process of "irregularization" that was set in motion through state and provincial policies and administrative requirements that ran counter to the official government discourse, which emphasized immigrant integration. Drawing on Calavita and other scholars in several disciplines, De Genova (2002) elaborated on the critical concept of the legal production of migrant "illegality." This approach to the undocumented does not take as given the term or the "problem" of the undocumented. Instead, De Genova calls for a critical examination of the social and political conditions under which people are legally and routinely constructed as "illegal." Theoretically, his project is related to Heyman's (2001) analysis of immigration classification, and also draws on Coutin's (2000) analysis of Salvadoran legalization as a legal process, rather than a study of a particular group (De Genova 2002, 423). We operationalize this call with an analysis of Canadian immigration and related policy that identifies the legal channels of immigrant entry and the ways that people can become "illegal," whether through unauthorized entry, or authorized entry followed by various pathways to illegality or precarious status. ${ }^{8}$

\section{Theorizing Illegality}

A second element of our framework involves consideration of the conception of illegality that one employs, which we propose is tied to the context and production of illegality. We concur with others who have sought more flexible ways of capturing various forms of legal status as an aspect of the exclusion experienced by non-citizens and, depending on the context, non residents. The literature includes several proposals that go beyond dichotomous conceptions. Menjivar (2006) introduced the concept of "liminal legality" to describe the experience of feeling legally and socially in-between among undocumented Salvadorans, many of them caught in a legal limbo. Drawing on the work of Victor Turner and Susan Coutin, Menjívar makes a key contribution by pointing out that the categories of documented and undocumented did not adequately capture the gray area of "liminal legality" experienced by the people among whom she worked. In this way, Menjívar was able to build on Coutin's insightful analysis of the "legal nonexistence" of undocumented Salvadorans by theorizing an additional category, that of liminal legality, which stands between being legal and being illegal, or undocumented and documented. In doing so, she echoes Bailey et. al's (2002) use of "permanent temporariness" to describe Salvadorans caught in the limbo of Temporary Protective Status.

A related non-binary conceptual move was made by Aleinikoff(1997, cited in Heyman 2001, 131), who conceived of US rights and membership as "circles of membership," a set of concentric circles, with citizens at the centre, and progressively larger circles of people with fewer rights and

\footnotetext{
${ }^{8}$ W ork by Black and his colleagues (2006) on routes to illegality among detainees in the UK is consistent with our approach to examining pathways to less-than-full status (Goldring and Berinstein 2003).
} 
Page 6

weaker belonging (permanent residents, followed by non-migrants and the undocumented at the outer edge). This echoes earlier hierarchical conceptions of citizenship that used the terminology of denizenship to describe non-citizens as long-term residents with limited or de-facto rights (Hammar 1990).

These contributions underscore the inadequacy of dichotomous approaches to legal status. However, we do not find them entirely satisfactory for the Canadian context for several reasons. First, the specific national or regional context in which migrant illegality is produced may generate different constellations of categories of legal status, each associated with specific configurations of rights or limitations. For example, liminal legality and related concepts used to describe the situation of Salvadorans under TPS rest on a tri-partite categorization: legality, liminal legality, and illegality, which is particularly valuable for understanding the undocumented and refugee experience in the United States, especially for Salvadorans. This model may overlap with elements of precarious status in other contexts, but it may obscure aspects of the production of illegality in other contexts. Second, processes of racial formation and negative racialization may intersect with the production of illegality in different ways depending on time and place. This, too, calls for a more flexible approach. Third, policies, regulations, and administrative practices change over time, leading to the re-classification of particular people or groups, something that needs to be investigated through context-specific and temporally dynamic analyses of the legal production of illegality. If the legal production of illegality and precariousness leads to a diverse array of marginalizing legal statuses, which can change over time and place, and operate unevenly across differentially racialized bodies and groups, then what is needed is a more robust way of defining and conceptualizing illegality and its production.

\section{Precariousness}

Our response is to use "precarious legal status" to describe various forms of non-citizen and non-resident status. This approach has the advantage of breadth: we use it to refer to variable forms of precarious status, including non-status. It also conveys a combination of ongoing risk and uncertainty, or ongoing vulnerability to precariousness, because it connects to the literature on precarious employment (Vosko 2006; Fudge and Owens 2006). That literature is attentive to the legal, political economy, and structural transformations that shape the context in which the terms of employment are being restructured in the direction of greater flexibility for employers, and greater instability and vulnerability for workers. In a similar fashion, citizenship and the rights associated with legal status are becoming increasingly precarious and conditional on requirements that are difficult to meet or maintain.

Borrowing this use of precariousness also points to the importance of locating discussions of citizenship and immigration status in the context of tendencies toward neoliberal citizenship and nation-building. We use this term to capture the twin tendencies on the part of states to restrict 
routes to citizenship and make citizens increasingly individually responsible for their existence. ${ }^{9}$ The former involves making citizenship more exclusive, the latter is part of a broader process of reducing the welfare state and social citizenship. This is consistent with Joppke's (2007) analysis of transformations in citizenship, which identified the contradictory tendencies of liberalizing access to the status of citizenship (for example, removing racialized and gender barriers); reducing social citizenship rights (while moving others right to the fore); and decoupling identity from citizenship (for example, through multicultural policies) (Joppke 2007, 38-39). This framework allows us to locate processes of irregularization and/or the legal production of illegality that generate precarious immigration status within a broader analysis of the political economy and cultural politics of citizenship, in which downward pressures on citizenship become normalized through cultural representations that contribute to the hegemonic, but necessarily incomplete, project of producing migrant illegality, worker flexibility, and responsible and deserving citizens.

\section{THE PRODUCTION OF ILLEGALITY IN THE CANADIAN CONTEXT ${ }^{10}$}

Canada and the United States share a border, historical links to England, the widespread use of English, and many cultural similarities. However, Canada differs from the United States in ways that make it a distinctive context for migrant entry, for the production of migrant "illegality," and for studying these processes. We begin this section with a discussion of Canada as a context for the production of illegality, making some comparisons to the United States. In the next part of the section, we describe the policy framework around legal entry. The section concludes with a discussion of pathways to precarious status and illegality.

\section{Different Contexts, Differences in Unauthorized Entry}

Canada's geography, immigration policy, and border enforcement landscapes are quite different from those of the United States, making the countries different contexts for the entry and reception of migrants (Reitz 1998; Goldring 2006; Bloemraad 2006). The border-related aspect of this difference is, perhaps, best illustrated with reference to the two countries' southern borders, the extent of unauthorized border crossing, and state and popular responses to unauthorized entry. In the United States, where much of the literature on undocumented migration is produced, the largescale unauthorized movement of migrants, primarily from Mexico, across the southern border accounts for most undocumented entries and the main pathway to undocumented status in that

\footnotetext{
${ }^{9}$ The parallel trend among countries of emigration is to transform emigrants into extra-local citizens who are co-responsible for development (see Landolt 1999; Lowell et. al 2000; Goldring 2005).

${ }^{10}$ An historical discussion is beyond the scope of this paper, so we focus on the contemporary period, with its roots in policy changes initiated during the 1970s under Prime Minister Pierre Trudeau.
} 
country. ${ }^{11}$ In 2004, the undocumented population in the US was estimated at 10.3 million people (Van Hook et. al 2005), and, as indicated earlier, the figure rose to 12 million in 2007 (Kiely 2007). As constant media coverage attests, the US government spends considerable resources on border enforcement, most recently in the form the construction of a controversial fence. Enforcement remains highly polemical, as migrants move to more dangerous crossing areas and the number of deaths at the border continues to climb. Responses to the presence of the undocumented run the gamut from large-scale marches and advocacy on their behalf, to criminalization and deportation. The visibility of unauthorized entry, and the presence of the undocumented are undeniable: the unauthorized population enters into public discussions and press coverage on a regular basis.

In contrast, although Canada has a large, relatively undefended southern border, it is with a relatively prosperous country. Unauthorized land entry is not considered important; other pathways to illegality and precarious immigration status are presumably more common. However, the absence of reliable data on unauthorized entry and the presence of unauthorized residents make comparison difficult. Reports on enforcement by the Canada Border Services Agency appear to support the claim about the relative insignificance of unauthorized border crossing. Most enforcement seems to take place in large urban centres, rather than on the border, and much of it is in pursuit of "fugitive criminals" (Corelli 1996) rather than immigrants without proper documentation who have not committed (other) crimes (Raymont and Tracey 2002). Border enforcement, in fact, has tended to be focused more on goods and arms than people. The apparent lack of concern by the state has been reflected, on the whole and until quite recently, in the relative absence of the topic in the press.

The issue emerges periodically in connection to crises. These include cases of relatively large-scale attempted unauthorized entry or asylum claims (Greenberg and Hier 2001), smuggling (Kaihla 1996; Richards 2001) or deportation (Mickleburgh 2000; Waldman 2006). More recently, the case of large numbers of Mexican refugee claimants in Windsor has captured media attention (Waldie et. al 2007). To elaborate on one example of large-scale unauthorized entry, in 1999, the arrival of four boats filled with about 600 smuggled Chinese migrants off the coast of British Columbia was widely covered by the media, generating what Hier and Greenberg (2002) called a "discursive crisis." In an analysis of the same incident, Mountz (2004) supported this interpretation, emphasizing that prevailing representations emphasized the violation of borders, sovereignty, and laws, by both the smugglers and the migrants. The language of crisis supports the contention that the presence of people without authorization to work or reside in Canada was not and is not understood as a pervasive or structural, if polemical, feature of Canadian life by the general public, as it is in the United States. Instead, it is considered an occasional aberration.

${ }^{11}$ Relatively few studies analyze the presence of people who enter the United States legally and then violate the terms of their visas by overstaying, and, thus, become unauthorized residents. For example, Powers et. al (2004) found that one quarter of respondents in the 1989 and 1992 Legalized Population Survey and its follow up had entered the US legally, but then became unauthorized immigrants. Three quarters had entered without authorization across the southern border. Mexicans and Central Americans accounted for a majority, but not all, of those surveyed. It is reasonable to think that the LPS might include a higher proportion of legal entrants who became over-stayers than found among the general undocumented population, as these people would have a stronger likelihood of legalization. However, we have no way of knowing. 
Since 2005, the issue of people without status has begun to receive more media and public attention in Toronto. The combined effects of a reported labour shortage in the construction sector, several high-profile raids and deportations, including one in which school children were used as "bait" to capture their parents (Globe and Mail Editorial 2006), and the work of activist organizations have helped to raise awareness of the issue. It is in this context that activist groups succeeded in working with Toronto City Council to have the Police Board adopt a "Don't Ask, Don't Tell" policy which limited officers in terms of their ability to ask about the immigration status of victims and witnesses (Cowan 2006). They also were able to gain acceptance for a "Don't ask, don't tell" policy at the Toronto District School Board (CBC 2007). Growing awareness of the issue is also reflected in the Social Planning Council of Toronto's production of a resource guide about services that are available to people regardless of their status (CSPCT 2007). These changes are important, however, the contrast with the United States stands. We propose that the relative invisibility of the topic is strongly related to Canadian immigration policy and trends, and popular understanding of how the policy operates.

\section{Trends in Canadian Immigration Policy and Patterns}

Canadian immigration provides for a variety of authorized entrance statuses for would-be permanent and temporary residents. Official discourse frames the policy as efficient and compassionate, because it selects qualified immigrants, supports family reunification, and admits refugees (CIC 2004a). The current policy framework was introduced with the 2002 Immigration and Protection Act (IRPA), which replaced the 1976 Immigration Act (CIC 2004a). The 1976 Act was important for several reasons. First, it institutionalized educational and occupational qualifications and investment potential as bases for selecting a majority of immigrants through the "point system" and investor programs. Second, it removed earlier source-country and regional criteria that expressed a racialized and racist hierarchy of eligible immigrants. This was linked to the new policy of Multiculturalism, which articulated the Trudeau era position on managing difference within Canada.

The 1976 Act led to significant diversification in the source countries and regions of immigrants, and helped change the face of the population in the three largest immigrant destinations: Toronto, Vancouver, and Montreal. This diversification is circumscribed by historical patterns and colonial history. The top source country for immigrants in 2001 was the United Kingdom, which accounted for 10.9 per cent of the foreign-born population. The other countries in the top five list point to subsequent history: Mainland China was in second place, with 6.1 per cent, followed by India with 5.7 per cent, Italy with 5.6 per cent, and the United States with 4.6 per cent (MPI 2004). In the United States, Mexican immigrants accounted for one third of the foreign-born population during the same year, but in Canada, no single national-origin group dominates in the same way.

Source country diversity has not necessarily translated into equity for immigrants, even those selected on the basis of education and skill. Critics point out that the policy framework introduced in the 1970s removed explicit racist language, but did not eliminate racist outcomes in the immigration and settlement systems (Simmons 1998; Bashi 2004). Once authorized immigrants 
Page 10

arrive, they encounter barriers that include problems with the recognition of foreign credentials and deteriorating wages and labour markets (Reitz 2005; Ornstein 2005; Wayland 2006). In an analysis of census data for Toronto, Ornstein found that "extreme economic disadvantage is highly racialized" (Ornstein 2005, vi). After accounting for the effects of age, education, and immigration, Ornstein also found that non-European groups were at a disadvantage in terms of income and employment outcomes, and that the income gap between European and non-European groups had grown since the 1970s (Ornstein 2005, v). His analysis also showed that groups from refugee producing countries were in a particularly vulnerable situation with respect to labour-force participation and income (Ornstein 2005, v), a finding echoed in related studies (Wayland 2006).

The 2002 IRPA retained the overall emphasis on labour-market and humanitarian criteria for selecting immigrants established in the earlier Act. However, it introduced crucial changes designed to address security, trade, and enforcement concerns which critics argued would make Canadian policy far more restrictive and consistent with American policy (Lowry 2002). Of particular relevance to our discussion was the introduction of the Safe Third Country Agreement, which was implemented in 2004. That Agreement requires refugees to seek asylum in the first safe country they enter after leaving their country of origin. The only exceptions are nationals from countries for which a visa to enter is not required Canada (for example, Mexicans). The Agreement meant that refugees from other countries making claims from the United States could be turned back at the border.

Under the IRPA, legal entry into Canada is possible as a non-resident tourist or visitor, in many cases with a visa required, and under various resident entrance statuses, some permanent, others temporary. We continue with a general overview of permanent and temporary entrance categories and trends before proceeding to a more detailed discussion of categories from which people are most subject to becoming vulnerable to precarious legal status.

\section{Permanent Residents}

Under the IRPA, there are three categories open to applicants for permanent residence to Canada. Potential immigrants can apply under the economic class, the family class, and the protected persons category. The first includes skilled workers, business immigrants, provincial nominees, and live-in caregivers, and their immediate family members. The family class includes spouses and partners, children, parents and grandparents of the sponsors. The last category is for governmentassisted and privately sponsored refugees selected abroad, individuals who are recognized in Canada as Convention refugees, or persons in need of protection, and those granted protection through the pre-removal risk assessment (PRRA) process (see PRAA below) (CIC 2004; CIC 2006a).

Figure 1 presents Canadian government data on permanent immigration to Canada between 1980 and 2006, broken down by entrance category. It shows an increase in the number and proportion of economic migrants, starting in the mid 1980s. The number of family-class entrants rose in the early 1990s, peaked in 1993, and then returned to lower levels. As a share of permanent entrants, however, the family class reached 50 per cent in 1984, but in 2006 was down to 28 per cent 
with 70,506 people. Refugees accounted for a relatively small, but steady, component of the total, although there is variation: they accounted for 28 per cent of the total in 1980, and 13 per cent in 2006.

Figure 1: Canada - Permanent Residents by Category, 1980 to 2006

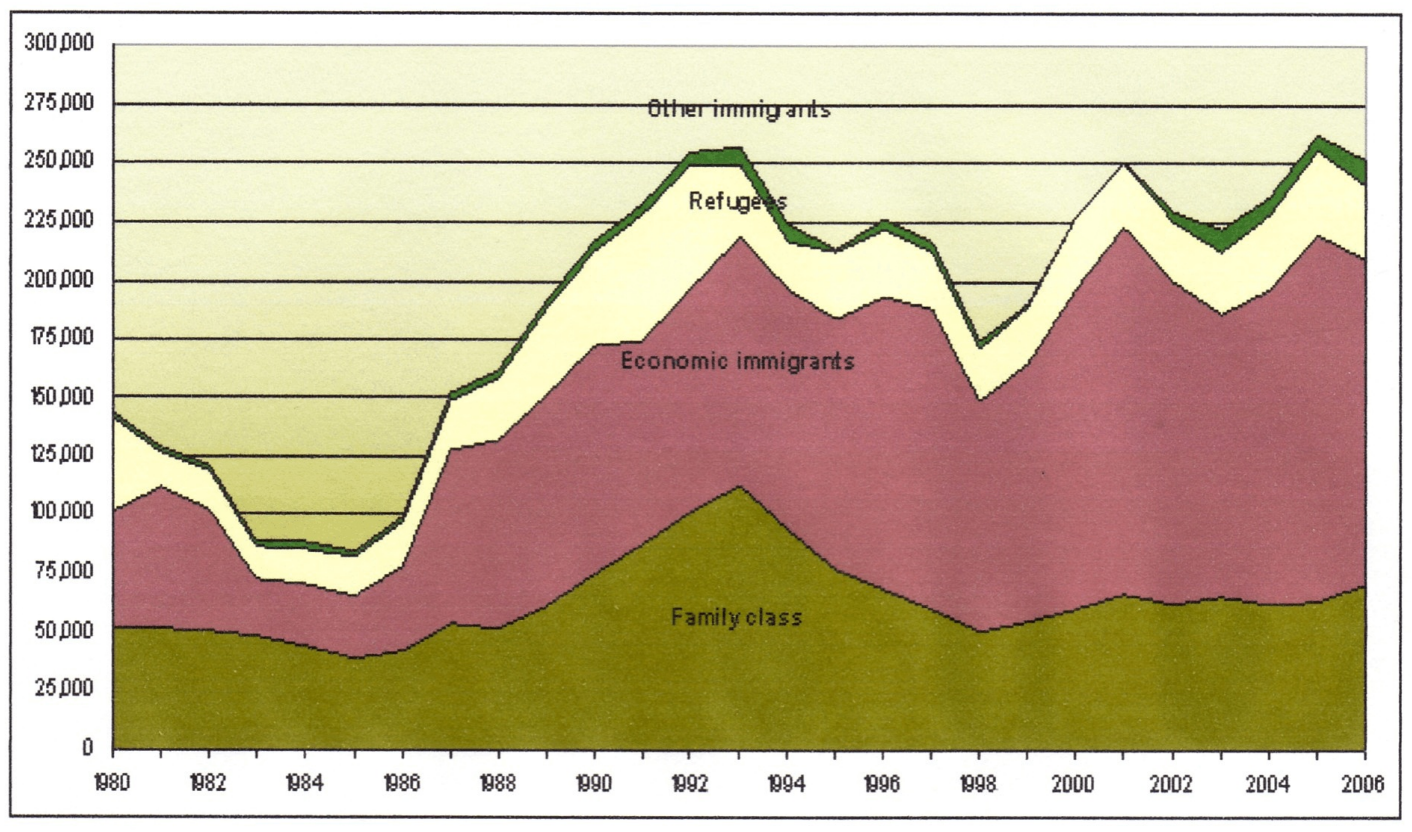

Source: CIC 2006a. "Facts and Figures 2006. Immigration Overview: Permanent Residents."

In Figure 2, we take these data and present them using trend lines rather than the area graph provided by CIC. This highlights three trends: (1) the importance of economic-class migrants relative to the other entrance classes, as seen in higher levels and the rising trend line; (2) the low proportion of refugee admissions coupled with a decline since the early 1990s and another drop in 2004; and (3) the drop in family-class admissions starting in the early 1990s. This graph underscores the centrality of economic and labour market priorities over family reunification and humanitarian concerns. 
Figure 2: Canada - Permanent Residents by Category, 1980 to 2006

Canada: Permanent Resident by Category, 1980-2006

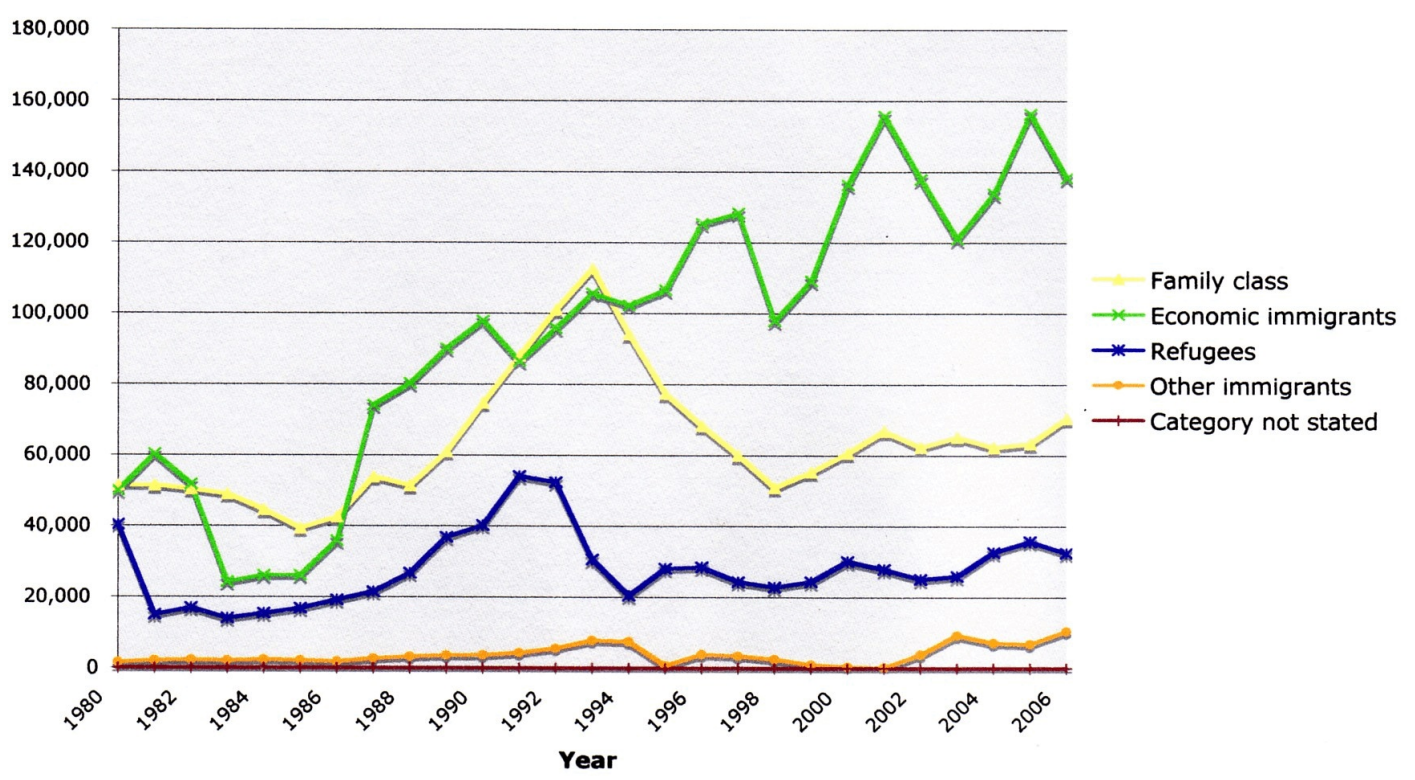

Source: Data adapted from CIC (2006a, 11).

\section{Temporary Residents}

Citizenship and Immigration Canada divides temporary residents into four categories, depending on their primary motivation: foreign workers, foreign students, humanitarian cases (refugee claimants and those granted residence on humanitarian and compassionate grounds), and other cases. The latter category is used for temporary residents who do not fit into the other categories (CIC 2006a, 59). The temporary-worker category includes work authorization programs for specific sectors and occupations, such as domestic workers (through the Live-in-Care Workers program), agricultural workers (through the Seasonal Agricultural Workers Programme), highly skilled workers (under NAFTA), and construction workers. The boom in Alberta's oil industry also has generated mechanisms for hiring temporary foreign workers for that sector (HRSDC 2006).

The numbers of people admitted into Canada under temporary categories (flow data) has fluctuated since 1980. However, data on the number of temporary residents present at any given time (stock data) show a clear increase over time. Figure 3 presents the annual flow of temporary residents by primary status, and Figure 4 does the same thing for the stock of temporary residents. The total annual flow surged in the 1990s and again at the beginning of the current decade. Higher levels in the stock of temporary residents indicate that some of the entrants stay long enough to increase the stock of temporary workers; that is, more stay than leave in any year. The stock data also show a sharp increase around 1990, this is part of a general rise in the presence of temporary residents present in Canada. The spike in flow and stock data just before 1990 included a significant 
increase in each of the temporary admission categories (Figures 3 and 4). CIC tabulations show the top three source countries of temporary workers in this period were the United States, Mexico, and the Philippines (CIC 2006a, 66). The number of US foreign workers has remained the highest, but since the late1990s, the proportion of the stock of temporary workers from the US has dropped, while that of workers from the Philippines has risen, and climbed slightly for Mexicans (CIC 2006a, 69).

Figure 3: Canada - Annual Flow of Temporary Residents by Primary Status, 19802006

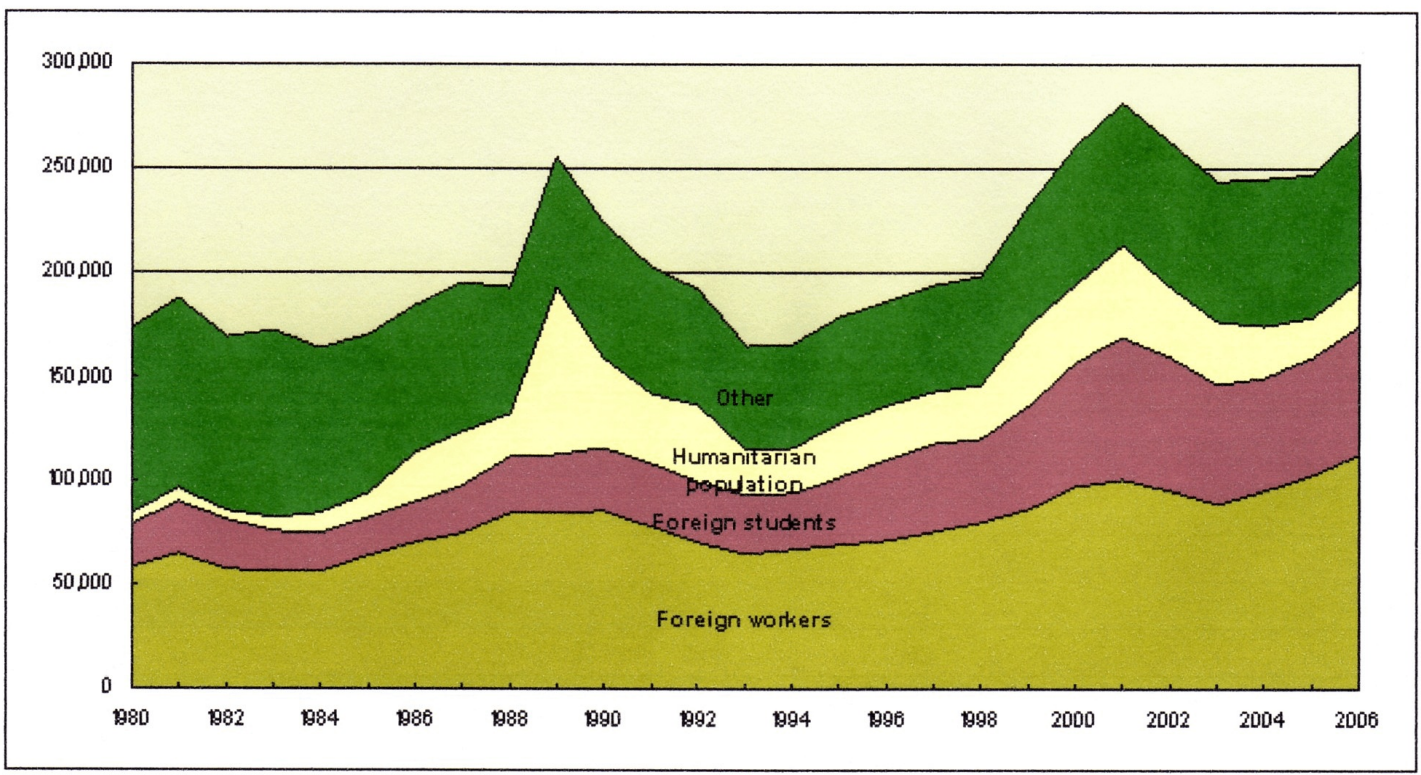

Source: CIC (2006a, 61). 
Figure 4: Canada - December 1 Stock of Temporary Residents by Primary Status, 1980-2006

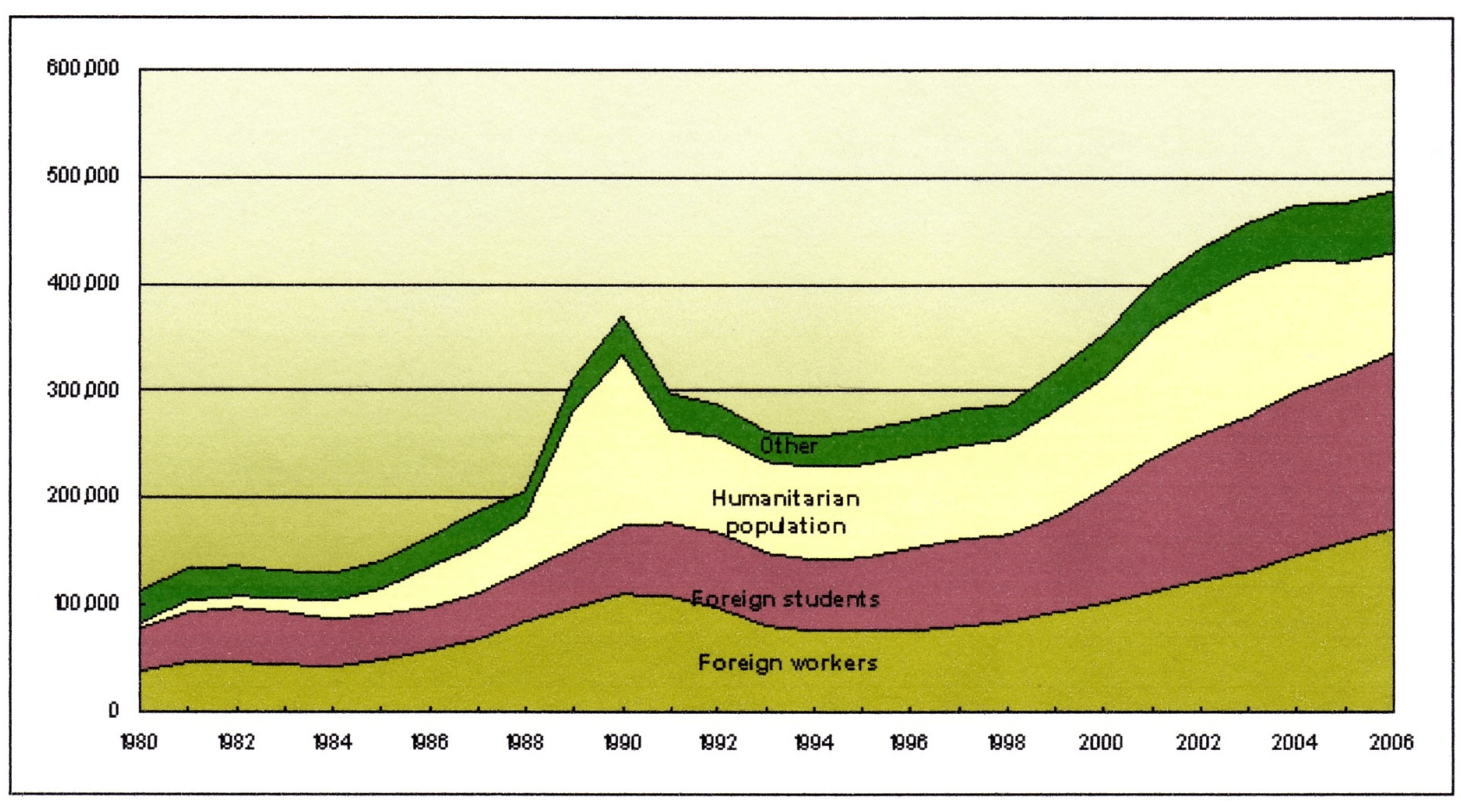

Source: CIC (2006a, 61).

Figure 5 presents data for the stock of temporary residents. It is based on the same data as shown in Figure 4, but it illustrates that in the time period it covers, the number of foreign workers rose considerably, as did that of foreign students. In contrast, the humanitarian population has fluctuated. The most recent decline after 2004 reflects the drop in applications at the border following the implementation of the Safe Third Country Agreement.

Canada's growing reliance on temporary workers is evident in Figure 5. The stock of foreign workers grew by four times between 1980 and 2006, starting at 39,234 people and increasing to 171,844 (CIC 2006a, 64-65). However, placing the temporary stock and flow data on the same metric together with the data on permanent entries puts the trends into sharper relief (Figure 6). 
Figure 5: Canada: Dec. 1 Stock of Temporary Residents by Primary Status, 19802006

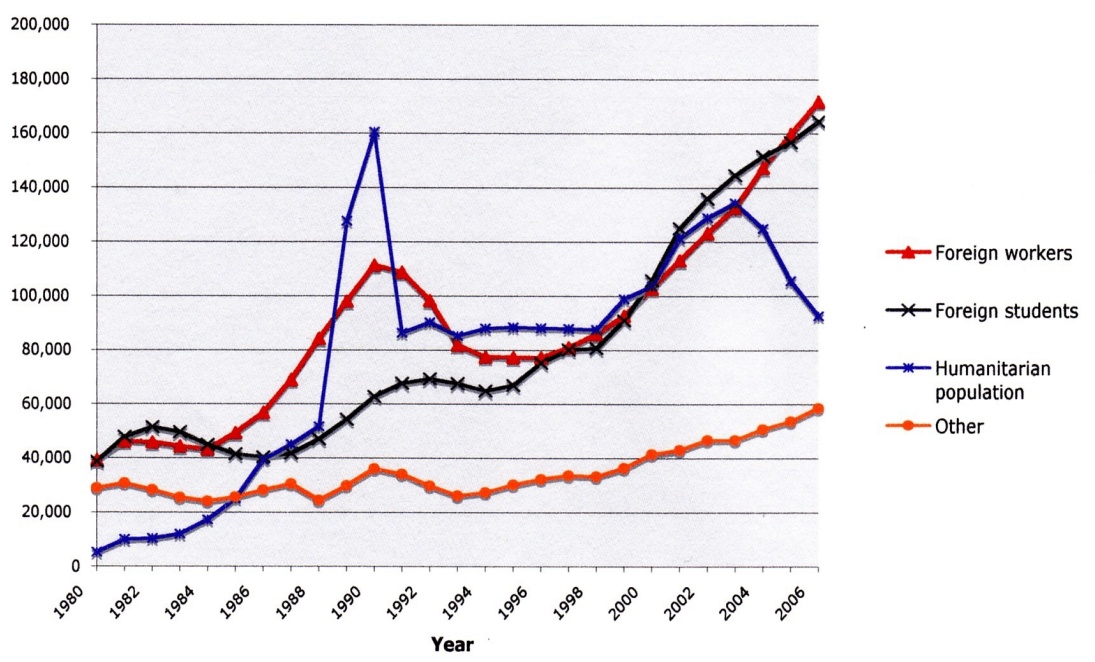

Source: Adapted from CIC (2006a, 64-65).

Figure 6: Canada: Total Flow of Permanent Residents, Stock and Flow of Temporary Residents, 1980-2006.

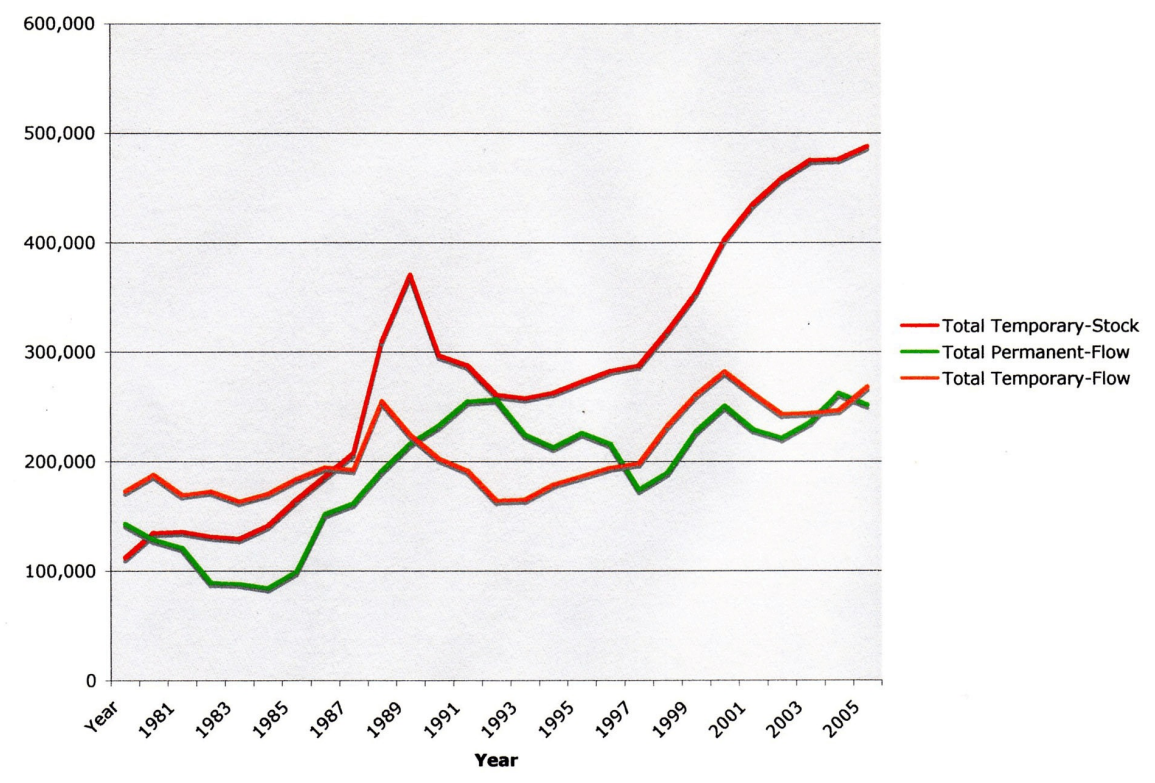

Source: Calculated based on data in CIC (2006a, several tables). 
Figure 6 shows that the number of temporary and permanent resident entries (flow data) has been fairly similar over time, with some fluctuations. It also shows that the stock of temporary residents has climbed quite steadily, suggesting that temporary residents account for a growing share of Canadian residents. Given what we know about the composition of temporary flows, it would appear that temporary entrants are staying on in Canada. The fact that immigration (and labourmarket) policy has shifted toward greater use of temporary admissions, particularly temporary foreign workers, has not gone unnoticed. Stasiulis and Bakan (1997), Sharma (2001), Basok (2002), and Preibisch (2004) have raised concerns over temporary- or migrant-worker programs, arguing that they generate a class of people who live and work in Canada without full resident rights, citizenship, and labour rights. This contributes to the social, political, and economic marginalization of temporary workers, and generates hierarchies of rights and membership within the Canadian nation. These analyses have shed light on crucial issues with respect to Canadian citizenship, inclusion, and society, for example by noting that long-term temporary residents lack many of the rights enjoyed by others. Our work contributes to this scholarship by analyzing the legal production of precarious status, including illegality.

\section{PATHWAYS TO SECURE STATUS, PATHWAYS TO PRECARIOUS STATUS}

The previous section sketched out the current policy framework regulating authorized entry for permanent immigrants and temporary residents. In this section, we describe selected entrance categories and procedures in more detail in order to show how Canada's immigration and refugee policies, government bureaucracy, and location institutionalize multiple pathways to various forms of precarious status, including deportability and illegality.

Entering Canada as a permanent resident places most, but not all, immigrants on a pathway to secure permanent status, including citizenship. In contrast, temporary-resident categories explicitly do not contemplate pathways to permanent residence or citizenship--with the exception of the Live-In Care Worker Program. However, permanent residents can lose their status either if they are convicted of an indictable offense or if they fail to maintain the stipulated residency requirements regarding time spent in Canada. In addition, if a relationship breaks down during the process of family sponsorship before the person being sponsored receives permanent status, her/his application becomes null. For refugees, the situation can be complicated, as is discussed in greater detail below.

\section{Family Sponsorship and Sponsorship Breakdown}

Canadian citizens and permanent residents who meet certain requirements may sponsor close relatives or family members who wish to reside in Canada. Sponsors are responsible for supporting the sponsored family member for a period of three to ten years, depending on their age and relationship to the sponsor (CIC 2002a). Sponsorship applications are usually processed while the person being sponsored is outside of Canada, but in the case of spousal sponsorship, partners being 
sponsored can be in Canada while the application is in process. A study undertaken by the Latin American Coalition to End Violence (LACEV 2000) documented the abuses that women in this situation can experience because of their dependence on the sponsor for their immigration papers and economic livelihood. In cases where a woman being abused chooses to leave the relationship before she has become a permanent resident, she will be left without any valid immigration status. In some cases, women have had children born in Canada while their applications were being processed and were unable to go back to their home countries even when the relationship broke down and they were left without status (Latin American Coalition to End Violence Against Women and Children, 2000). The gendered dimension of this pathway to loss of status is particularly salient. There is anecdotal evidence that sponsorship breakdown disproportionately affects women and children, but there are no data on the topic. ${ }^{12}$

\section{Refugee Policy and Process: Protection and Precariousness}

Canada's refugee determination system is grounded in the United Nations Convention relating to the Status of Refugees, the 1984 Convention Against Torture, and to the International Covenant on Civil and Political Rights, to which it is a signatory. This system offers protection to persons outside their home country who have "a well-founded fear of being persecuted for reasons of race, religion, nationality, membership in a particular social group or political opinion" or who face a substantial risk of torture or to their life, or of cruel and unusual treatment or punishment (CCR 2002). The Canadian public may be aware of the refugee backlog problem, and may be concerned about the veracity of refugee claims, particularly during moments of crisis, such as the September 2007 arrival of Mexican claimants at the border in Windsor (Waldie et. al 2007). However, most people are not aware of the ways in which the system contributes to the institutionalization of precarious legal status.

Canada's Immigration and Refugee Protection Act provides two avenues for refugees to receive protection: one is an overseas resettlement program and the other is an inland application process. The former are classified and counted along with permanent residents, while the latter are grouped with temporary residents. Refugees can be brought from overseas either with assistance from the Canadian government, or if sponsored privately by groups of Canadians. According to one report:

Refugees who are resettled from overseas usually become permanent residents as soon as they arrive in Canada. However, in some urgent cases, processing is not completed by the time the refugee family arrives and several months or more pass before they become permanent residents (CCR 2002).

\footnotetext{
12 Personal communication, Rhonda Roffey, Executive Director of Women's Habitat, Toronto, a shelter for women in crisis, 17 October 2007.
} 
Page 18

In 2006, 7,316 government-assisted and 3,337 privately sponsored refugees were admitted in Canada (CIC 2006a, 3). During the waiting period, these seemingly "permanent resident" refugees, are given temporary work authorizations, which must be renewed, and Social Insurance Numbers that start with a 9, which signal their non-permanent or precarious status. Although they have work authorization, some employers may not want to hire people whose status determination has not been finalized.

Refugees are also able to make a claim for refugee status at any Canadian border or from within the country. Since 1985, when the Supreme Court of Canada rendered the Singh decision, persons seeking inland refugee protection are entitled to an oral hearing as part of the determination process. The Supreme Court ruled that refugee claimants are entitled to "fundamental justice" and that this would normally require an oral hearing (Dench n.d ). However, the Safe Third Country Agreement now has restricted the eligibility of applications made at the Canada-US border.

Not all claims are successful. According to Immigration and Refugee Board statistics compiled by the Canadian Council for Refugees, 40,408 refugee claims were finalized in 2004. Of these, 16,005 or 40 per cent were accepted and 19,180 (47 per cent) were rejected (CCR 2004). In 2006 , the number of claims finalized fell to 19,828. Of these, 47 per cent were accepted, 41 per cent were rejected, and the remaining 12 per cent were abandoned or withdrawn (CCR 2007). Not all the applicants who were rejected were immediately removed from Canada, largely because the federal government does not have the resources needed to issue and enforce all removal orders. In effect, there are, at any given time, tens of thousands of denied refugee claimants with a legal right to be in the country whose status is precarious and who are subject to deportation. A 2003 press release from the Auditor General of Canada indicated that "the gap between the number of removal orders issued and the number of confirmed departures has grown by about 36,000 over the past six years" (Auditor General 2003).

The inland and border refugee determination process is lengthy and involves various forms of precarious status along the way. Moreover, the restrictions imposed by the IRPA have reduced the number of such applications. Furthermore, failing to fulfill certain requirements in time may lead to a loss of status and the production of illegality. For example, refugee applicants are granted legal status as refugee claimants once their refugee claim is determined to be eligible by Citizenship and Immigration Canada. Persons who make their applications at a point of entry to the country generally have this determination made immediately, and enter the country with legal, yet limited status. Persons who do not make their applications until they are inland, however, have to wait several months for their claims to be deemed eligible. During this waiting period they are known to authorities (are documented), but have no legal status recognized by the Canadian government, yet another form of precarious status.

As mentioned above, eligibility for making a refugee claim is determined by Citizenship and Immigration Canada. In 2004, 234 claims were found ineligible to be determined by the Immigration and Refugee Board (Dench p.c.). Persons are deemed ineligible if: 1) they have previously applied for refugee status in Canada; 2) they have convention refugee or protected status in another country to which they can return; 3) they have been determined to be inadmissible on 
grounds of security, human rights violations, serious criminality or organized criminality, or, 4) they have come to Canada by way of a "safe third country."

The Safe Third Country Agreement has had a chilling effect on the number of refugee applications. For many refugees who cannot find direct routes to Canada, in some cases because there are no direct flights, this means that they are forced to make their claim in the United States where acceptance rates are lower. For example, Mary Jo Leddy, the director of Romero House (a refugee shelter in Toronto), was quoted by the Canadian Broadcasting Corporation as saying "We know that the Colombians who are desperate, who would be accepted here, are not going to be accepted in the US" (CBC 2005). In July 2005, seven months after the implementation of the Safe Third Country Agreement, Citizenship and Immigration Canada reported a 40 per cent reduction in the number of claims for 2005, compared to the same period during the previous year (CBC 2005). Information on the number of claims finalized between 2003 and 2006, that is, the number deemed eligible for review, shows the decline more starkly. In 2003, 42,477 claims were finalized. The figures were 40,408 in 2004, 27,212 in 2005, and 19,828 in 2006 (CCR 2007). Critics speculated that these changes could result in more people finding alternate means of entering Canada, which would lead to the presence of more people without recognized legal status.

The process of refugee classification and determination long has been linked to political agendas and international relations priorities around the world (Basok and Simmons 1993; Nef 1991; Richmond 1984; Adelman 1983). In recent years, security concerns have come to the fore (Menjívar 2006; De Genova 2002; Koser 2001). The configuration of countries considered to produce legitimate refugees may vary, but Canada is no exception to the pattern (Lowry 2002; Lacroix 2004). Canada designates some countries as refugee-producing countries, while others are not. Adjudicators from the Immigration and Refugee Board who hear refugee claims are trained and take into account Board guidelines and government policies (for example, the Safe Third Country Agreement), but there is nearly always some element of subjectivity, which produces variations in the outcomes from the determination process. Changes in the process of selecting members for the Immigration and Refugee Board, the IRPA's reduction of the number of members involved in making a decision from two to one, the failure to institute the Refugee Appeal Division, and other changes associated with the IRPA have led to many changes in the refugee determination process over a short period of time. The Canadian Council of Refugees website includes material from lawyers, former IRB members, and others who are concerned about the quality of decisions being rendered (CCR 2006b).

Data on approved versus rejected claims can be broken down to reveal important countrylevel differences, some of which have changed over time. IRB data on countries ranked in the top 20 for the number of decisions finalized, which are available from the Canadian Council of Refugees, show, for example, that in 2005, countries such as Colombia, Iran, and Sri Lanka had fairly high and consistent approval rates (79 per cent for Colombia, 75 per cent for Iran, and 67 per cent for Sri Lanka). Refugees from other countries, such as Mexico (19 per cent), India (25 per cent), and Guyana (18 per cent) exhibited lower rates of acceptance. Cases such as Costa Rica illustrate fluctuations in the acceptance rate that are not easily explained: Costa Ricans had a 17 per cent acceptance rate in 2005, which was up from 3 per cent in 2004, and 2 per cent in 2003 (CCR 2006a). The case of Mexican refugee claimants also illustrates tensions in the system. Mexico is 
not an officially designated refugee-producing country, nor is it thought of as a conflict zone, something reflected in the high rejection rates for Mexican refugee applicants. However, the number of applications from Mexico placed it at the pinnacle of the top-20 ranked countries, and acceptance rates have fluctuated, going from 25 per cent in 2004 to 19 per cent in 2005, and up to 28 per cent in 2006 (CCR 2007).

Variations in acceptance rates according to the Canadian region in which refugee hearings took place, the current backlog in claims (23,476 in 2006) (CCR 2007), criticism of IRB procedures and its member selection process, and other problems have contributed to concerns, from various ends of the political spectrum, about Canada's ability to fulfill its humanitarian obligations (CCR 2006b, 2007b; Stoffman 2002). Our purpose in raising these issues is not to analyze the politics of refugee determination, something beyond the scope of this paper; rather, we want to emphasize the complexity of the process, and show that while there are avenues for refugee entry (which are narrowing), there are also many opportunities for people to move into forms of precarious immigration status as they navigate through the system.

\section{Temporary Workers}

Canada is home to an increasing number of temporary residents, which include foreign workers (CIC 2006a). Seasonal agricultural workers, construction workers, live-in caregivers, hightech experts and others have been admitted to Canada under special programs granting them temporary work permits. While each program has its own unique characteristics, what they have in common is that they tie workers to a particular employer, making them vulnerable to mistreatment and abuse. If an employment relationship is severed, the worker may be left without any valid immigration status. The programs also vary with respect to workers' eventual eligibility to apply for permanent residence and citizenship. For example, live-in-care workers eventually can apply for citizenship, but agricultural workers cannot. Technically speaking, temporary workers have some legal status in that they are authorized to live and work in Canada. At the same time, it is a precarious status, since, by definition, temporary status means one is not a permanent resident, lacks rights, and is not a full member of society. Furthermore, in most cases temporary residents will never be eligible to become permanent. As we will show, falling out of the status afforded by these programs compounds people's vulnerability and precarious status.

\section{Seasonal Workers}

The Seasonal Agricultural Workers Program (SAWP) brings approximately 15,000 workers from Latin America and the Caribbean to Alberta, Quebec, Manitoba, Nova Scotia, New Brunswick, Prince Edward Island, and Ontario for periods of three to ten months a year. Workers who do not meet an employer's standards can be removed from the list of workers hired the following year. During the period of the contract, workers are separated from their families and face issues such as isolation, discrimination, and occupational health and safety hazards (Justicia for Migrant Workers 
2005; Preibisch 2004; Basok 2002). If a worker leaves his or her employer, s/he looses the authorization to be and work in Canada, although in some cases, workers are given time to find another employer.

\section{Entertainers}

Canada used to provide "Entertainer" visas for women from various Latin American, Eastern European, and Southeast Asian countries to come work as exotic dancers. Again, in these situations, women often have found themselves vulnerable to having wages withheld, overcrowded living conditions, and other forms of abuse and harassment from their employers (Latin American Coalition to End Violence Against Women and Children 2002; San Martin 2004). In 2004, this program was shut down after a scandal referred to as "strippergate" broke when the then-Minister of Immigration, Judy Sgro, was accused of wrongly helping a Romanian exotic dancer prolong her stay in Canada (Freeze and Jimenez 2004).

\section{Construction Workers}

In 2001, the Greater Toronto Home Builders' Association entered into a sectoral agreement with Human Resources Development Canada and Citizenship and Immigration Canada to permit entry of up to 500 temporary foreign workers to fill some of the labour gaps in the residential construction industry (CREWS n.d.). Initially a two-year pilot programme, Citizenship and Immigration Canada and Human Resources and Skills Development Canada renewed their Memorandum of Understanding on 24 September 2004 for a three-year period. This program appears to be less restrictive than other temporary-worker programs, because it gives certain skilled workers the opportunity to bring their families to Canada during the length of their contract (CREWS n.d.). However, the application process for the CREWS program is complicated, not well known, and has not resolved either employers' needs for a stable work force or workers' demands for regularization.

\section{Caregivers}

The Live-In Caregiver Program brings workers to Canada to perform live-in work as caregivers for children, elderly persons, or persons with a disability. To date, women from the Philippines and the Caribbean have been the main participants in this program. After completing two years in the program, participants can apply for permanent resident status (Kelly 2006; CIC 2002b; Stasiulis and Bakan 1997; Arat-Koc 1997; Cohen 1994). While the program provides women with income, critics have noted various problematic issues including sexual harassment and labour violations that may emerge because employees depend upon their employers to remain in the program and, thus, to become eligible for permanent resident status (Makeda 1983; Arat-Koc 1997). 
Page 22

Scholars also have noted that immigration policy has established increasingly higher requirements for women entering the program, while maintaining downward pressure on their rights (Stasiulis and Bakan 1997; Cohen 1994).

\section{Other Temporary Residents: Visitors and Students}

Citizenship and Immigration Canada issues Visitor visas to people who wish to enter Canada for a temporary purpose. These visas are usually issued for a period of six months. There are also fewer than fifty countries from which citizens do not require visas to enter Canada. ${ }^{13}$ In 2005 , 920,664 temporary visas were issued for tourists and business visitors to Canada, a 7.6 per cent increase over the previous year. In addition, 105,149 visitor records were issued. ${ }^{14}$ Student authorizations were issued to 61,703 foreign students to study in Canada in 2006, and the total number (stock) of foreign students in that year was 156,955 (CIC 2006a, 78, 81). Since Canada does not have exit controls, it is impossible to know, with any degree of certainty, how many people on temporary resident permits stay in the country after their permits have expired.

\section{Recourse after Falling Out of Status}

The preceding discussion has shown various ways by which people who enter Canada legally may lose their original immigration status, and enter into a situation where they remain in, or move between, different forms of precarious status. When this happens, there are a few, but rather limited, options for attempting to regain the lost status.

\section{Judicial Review}

A judicial review:

is not an appeal, but a review of the IRB decision to see if the Board member followed all the legal rules in making the decision. It has to do with technicalities of

${ }^{13}$ However, this list of countries is subject to change. For example, people from Costa Rica did not need a visa to enter Canada, but now do. When these regulations change, it is very likely that people will get caught in situations where members of a family have different legal statuses, including less than full or no status.

14 This represented a decrease of about 11 per cent over 2004. According to CIC, visitor records are issued to "foreign nationals who want to stay in Canada for over six months without working or studying, visitors who intend to work but who are not required to obtain a work permit, and business visitors under the North American Free Trade Agreement who provide after-sales service for longer than two days" (CIC 2006b). 
law, with any mistakes that were made in determining the case (FCJ Refugee Centre 2005).

In 2004, 12 per cent of applications to the Federal Court for judicial review of decisions made by the Immigration and Refugee Board Refugee Protection Division were granted. Of those, nearly half (43 per cent) of the reviews overturned the original negative decision (Dench p.c.).

Pre-Removal Risk Assessment (PPRA)

Anyone who has been issued a deportation or removal order is entitled to undergo a PreRemoval Risk Assessment. In order to be successful with a PRRA application, it must be demonstrated that if she/he returned home, the applicant would face a serious risk not faced by others in the same country. Only new information can be presented at this stage, and legal fees for this avenue are rarely covered by Legal Aid Ontario. In 2004, there was a 2.7 per cent acceptance rate for PRRAs (Dench p.c.). In 2005, only 3 per cent were accepted (CCR 2006b).

\section{Humanitarian and Compassionate Applications}

Anyone living in Canada without recognized legal status is eligible to make an application for permanent residency based on humanitarian and compassionate considerations (known as an $\mathrm{H}$ \& C application). Applicants must prove that they would face "undue hardship," due to circumstances beyond their control, if they were to return to their home countries. Furthermore, they must also demonstrate "successful establishment" (which focuses on financial establishment) in Canada. Applications of this sort can take several years to be determined, and submission of an application will not automatically stop a removal or deportation order. Application fees are $\$ 550$ per adult applicant, and $\$ 150$ per applicant under 22 years of age. Although there are no official statistics from Citizenship and Immigration Canada on the rate of acceptance for $\mathrm{H} \& \mathrm{C}$ applications, immigration lawyers and advocates agree that it is between 2.5 and 5 per cent. There is no appeal or review recourse in cases of a negative $\mathrm{H} \& \mathrm{C}$ decision.

\section{PRECARIOUS STATUS, PRECARIOUS ACCESS TO SERVICES AND SOCIAL EXCLUSION}

A person's citizenship and immigration status in Canada, as elsewhere, plays a decisive role in shaping the rights and services to which she/he is entitled and/or has access (Calavita 1998; PCLS 1998; Sharma 2001; Goldring and Berinstein 2003; Basok 2004). Access to services, in turn, contributes to people's wellbeing, health, social inclusion or exclusion, and sense of belonging to society (Omidvar and Richmond 2003; Berinstein et. al 2006; Goldring and Berinstein 2003; Bernhard et. al 2008). Examining the relationship between immigration status and access to 
services, thus, becomes central to theoretical and policy discussions regarding citizenship rights and immigration status, as well as for understanding the lived effects of precarious status and illegality, and the possibilities for organizing for change.

We recognize that formal entitlement is not the main, or the only, factor that determines access to services or related aspects of life, such as wellbeing. Citizenship theorists have pointed out that class, gender, age, and racialization can limit access to services and generate inequalities among people with formal rights (Lister 1997; Barbalet 1988; Stasiulis and Bakan 1997; Goldring 1998). In some situations, the inverse may hold: lack of citizenship or permanent residence status may not necessarily limit access to services if these are provided through other institutions (private or public). Similarly, the absence of formal citizenship does not necessarily stop people and social movements from struggling to obtain or expand their substantive and formal citizenship (Brubaker 1990; Goldring 1998; Guang and Jin 1996; Lowry and Nyers 2003; Wright 2003). Moreover, in Canada, as in other localities, there are organizations that provide some services to people with various forms of precarious status and illegality, mitigating the effects of their legal status (Berinstein et. al 2006; CSPC-T 2007).

Formal citizenship and immigration rights and regimes, however, do make a difference in people's everyday lives (Marshall and Bottomore 1992; Basok 2004; Kymlicka 1995; Richmond 1994). As we discuss below, in Canada, federal and provincial health-care provisions limit access to some services, including health, to people with specific citizenship or immigration statuses. More generally, citizenship regimes and the rules governing citizenship acquisition shape the way immigrants are incorporated and minority groups are treated in multicultural societies (Castles and Miller 2003; Richmond 1994), particularly under conditions of differential incorporation (Portes and Rumbaut 1996) or segmented assimilation (Portes and Zhou 1993; Labelle and Salée 2001).

In Toronto, several factors contribute to variations in the ways that agencies deal with immigrants and refugees without full status. One is the legal ambiguity and relative invisibility of the topic of immigration status. A second involves the ways in which immigration policies generate confusing forms of precarious status, as outlined earlier. Third, there are agency-based institutional differences and constraints that have to do with funding sources (some monies can be used for people without status or in some form of precarious status, others cannot) and workplace or organizational culture (what an Executive Director supports, stresses, and the like). This translates into diverse experiences for people in situations of precarious status. Some obtain access to some rights and services, and others do not, which creates ongoing confusion about who is entitled to what, for both service providers and users. The remainder of this section highlights the importance of the relationship between legal status and access to services in Ontario through a discussion of selected statuses and associated entitlements to social services, and how agencies deal with the ambiguity of precarious legal status. ${ }^{15}$

\footnotetext{
${ }^{15}$ We have limited our discussion to Ontario because many of the services we discuss are provincial, or receive federal funds but are implemented according to provincial policies. An analysis of provincial variations in the provision of services is beyond the scope of this paper.
} 


\section{Refugee Claimants}

Refugee claimants have limited rights to health care, education, social services, income support programs, and employment protection. They are eligible for social assistance, employment insurance, and workers' compensation, and they can apply for a work permit and belong to a union. They are not eligible, however, for federally funded settlement services, such as employment training and Language Instruction for Newcomers to Canada (LINC), making it very difficult for them to receive language training. ${ }^{16}$ While they are eligible for provincially funded English as a Second Language (ESL) classes, that program does not provide childcare services or public transportation tickets, which limits access for mothers with young children and those on fixed incomes. Refugee claimants' children do, however, have access to public schools. With respect to health care, refugee claimants are covered by the Interim Federal Health Plan, but this only provides them with "urgent and essential services." This does not include things such as infertility investigations and treatment, routine circumcisions of newborns, over-the-counter medications, even when written on a doctor's prescription, or root canals (CIC 2001).

Denied refugee claimants maintain their entitlements if they file for a judicial review, or while their PRRA is being determined, or before their removal date. If they choose to remain in Canada past their removal date, however, they lose any legal rights to be in Canada and most entitlements that they had. This situation will be elaborated on below on the section on persons with no status at all.

\section{Sponsored Family Members}

While a sponsorship application is in process, whether the person waiting for a decision is here legally (as in the case of a spouse), or not (as in the case of any other family member), does not make a difference when it comes to entitlements to publicly funded services. Before a positive decision is rendered, sponsored family members do not have any entitlements: they cannot study, work, or receive health or social services. In situations of sponsorship breakdown due to problems in the relationship, the spouse loses any entitlements and access.

\section{Temporary Workers}

As mentioned earlier, each program has its own guidelines as to whether participating workers are entitled to health, social, or education rights. In the Construction Recruitment External Workers Services Program, for instance, families are allowed to accompany the worker, and the spouses of certain designated trades-people are eligible to apply for an open work permit while they

16 LINC classes are available to convention refugees and permanent residents. 
Page 26

are in Canada to accompany their spouse. However, the spouses of construction labourers are not eligible to work in Canada during their stay (CREWS n.d.).

Caregivers and seasonal and construction workers are all entitled to provincial health care after their initial three months in Canada, although, in practice, it appears that many of them are not aware of this entitlement and, therefore, are unable to exercise it. Similarly, while, in theory, workers participating in these programs are entitled to employment rights and services, in practice, many of them find that they will be sent home early or that their contracts will not be renewed if they try to access benefits such as employment insurance or workers' compensation (Raper n.d.).

\section{Visitors and International Students}

Persons with valid visitors' or student visas are legally entitled to be in Canada, but generally not entitled to receive any publicly-funded services because they are seen to have made a choice to come to Canada for tourism or study, and it is assumed that, having made that choice, they should be financially self-sufficient. Even community health centres in Ontario, which receive some provincial funding to provide services to non-insured persons (see below), are excluded from providing services to persons with valid visitor and student visas. Children of parents in this category can attend public schools, but they have to pay foreign-student fees in order to do so. With some limited exceptions for students, people in this group are not entitled to work in Canada.

\section{Persons with No Status}

Persons from any of the above groups who choose to stay in the country after a final negative decision, or after a visa has expired, have no recognized legal status. They are not legally entitled to work, although if they find work in the underground economy they could, theoretically, in some circumstances, access workers' compensation. People without any legal status have very limited access to publicly funded health care, social services, and employment protections. In the area of health care, persons with no status are not entitled to provincial health insurance, but they are eligible to receive primary care at a local community health centre. Centres that do work with people without status tend to have long waiting lists. People in this situation also can receive emergency hospital services for which they subsequently will be billed.

People without status are not entitled to receive either settlement services or social assistance or to participate in federally funded language instruction classes. Their minor children however, are legally required, and, therefore, entitled, to attend school. Unfortunately, school board responses across the province of Ontario have been inconsistent with the legislation and with each other (Koehl 2007). Not only each school board, but in some cases, individual schools, have interpreted the legislation in different ways. At worst, this leads to children being denied access to school, and at best, to parents being required to prove that they are out of status in order for the children to be 
granted access (Koehl 2007). In May 2007, the Toronto District School Board approved a "Don't Ask, Don't Tell" policy with respect to the immigration status of parents (CBC 2007). It is too early to tell how the implementation of this program has proceeded.

\section{Ambiguity and Precariousness in Service Delivery}

In the context of health and social services, organizations often ask for identification to establish status and entitlement. Needing to show identification is problematic because it causes fear in people with precarious or no status, and often results in that person choosing not to come forward for a needed service because of their fear about being reported to Citizenship and Immigration Canada.

For example, in the case of public elementary education, The Toronto Public District School Board's (TDSB) policy states that it admits non-status children, but not tourists. For persons who enter Canada with a visitors' visa, this results in having to let that document expire so that their children can attend school. Moreover, although the TDSB has a clear policy, it is not always followed consistently. This causes confusion among service providers and non-status persons trying to register their children for school. This inconsistency between law and practice makes it difficult for advocates to challenge the issue in a systemic way, because, in theory, there are no barriers to access (Berinstein et. al 2006).

In the area of social assistance, a person is eligible for social assistance when she/he makes an application to stay in Canada on Humanitarian and Compassionate grounds, though being on assistance very likely will jeopardize his/her chances of getting status because it would be difficult for such an individual to prove 'successful establishment.' A person with a deportation order against her/him is not eligible for assistance unless she/he can prove that she/he cannot leave Canada for situations beyond her/his control (that is, from a country to which Canada is not deporting people, or if arrangements have not yet been made for the deportation to take place).

In terms of settlement services, agencies that receive federal or provincial funding to operate (the vast majority), cannot serve some less-than-full-status or non-status individuals; therefore, they are forced to turn people away, or to serve them anyway without being able to statistically report the services provided. This adds to the burdens of an already overworked and underpaid group of workers.

In the area of health care, a person is only eligible for Ontario public health insurance (OHIP) if they can demonstrate that they have a legal right to reside in Canada (Canadian Citizen, a permanent resident, and certain types of workers). In addition, all new immigrants to Canada have a three-month waiting period before they are eligible for OHIP coverage. Community Health Centres (CHCs) receive their core funding from the Ontario Ministry of Health and Long-Term Care, and a portion of these funds are directed towards serving non-insured populations. These typically cover primary care and lab work, although current non-insured funding levels are not sufficient to meet the demand for services in many of Ontario's major cities, and, as a result, CHCs 
Page 28

often find themselves with long or closed waiting lists. Individual CHCs will advocate for their noninsured clients who need tertiary care, by negotiating "OHIP rates" as opposed to "tourist rates" with hospitals.

\section{DISCUSSION}

We set out to examine the production of illegality in the Canadian context, and to identify some of its practical and theoretical implications. The general review and more detailed analysis of Canadian immigration and humanitarian policy showed that such policy provides avenues for both permanent and temporary documented entry. From these legal permanent and temporary entrance statuses, there are pathways that routinely lead some people to lose, or fall out of, legal status. This part of the analysis pointed to a strong similarity between the Canadian context and Calavitta's (1998) characterization of Spanish immigration policy as "irregularizing" newcomers. If we look closely at this process, it becomes clear that instead of legally producing unambiguous illegality, Canadian policy produces a variety of complex immigration status situations, as well as documented illegality. This calls for drawing a distinction between documented and undocumented illegality. De Genova's (2002) conception of the legal production of illegality is critical to building this conceptual distinction, but it also requires a contextual approach, one that considers how specific national contexts produce illegality.

Having established that policy routinely produces various forms of irregular status and documented illegality, the question remains as to how best to understand the forms of less-than-full status. Our analysis of the pathways to loss of immigration status, together with the discussion of the implications for access to public services (and various rights, such as labour rights), supports our use of the term precarious status to conceptualize the situation in Canada. It is important to understand both how people end up in various situations of precarious immigration status, and that then, depending on the pathway to precarious status and their location and possible contact with various service organizations, they may have access to a few, but not all, public services. That is, there is not one unitary gray area or liminal legality between legal and illegal. Rather, there are multiple of shades of gray.

The theoretical precedent established by scholars who articulated non-binary approaches to legal status is fundamental to our work (Calavita 1998; Menjívar 2006; Coutin 2000). At the same time, we stand by the use of precarious status to refer to plural forms of precarious status and documented illegality in the Canadian context. The context of Canada, and that of Spain at the time of Calavita's research, may not be exceptional, but a comparative analysis of contexts of production of precarious status and illegality is beyond the scope of this work. Our analysis, however, can be used to advance theoretical approaches to precarious status by underscoring the importance of at least five sets of contextually specific factors that shape the production of illegality: ${ }^{17}$

\footnotetext{
17 There are, of course, other important factors at play. These would include enforcement and surveillance technologies, border enforcement, the hegemony of anti-terrorism discourse, securitization, and the like.
} 
- 1) location/geography,

- 2) immigration and refugee policy,

- 3) main modes of legal and unauthorized entry,

- 4) pathways to loss of status, and

- 5) access to and provision of services to people with precarious status.

Taking these into account is a way of contextualizing the project of theorizing forms of illegality and precarious status, and pushing it in a comparative direction.

Canadian immigration policy demonstrates two trends that suggest that the number of people with precarious immigrant status and documented illegality is going to grow. The chilly climate for refugee claimants may produce decreases in the overall number of applications (because of the Safe Third Country Agreement). However, changes to the IRB process suggest that applications will continue to be rejected, and with fewer opportunities for recourse. More restrictive immigration policies also may have the unanticipated effect of increasing the number of people who overstay their visas because other options for entering and remaining in Canada are narrowing. Furthermore, there is no reason to believe that sponsorship breakdown, and other ways of entering precarious status, would suddenly disappear. Considering these directions and trends in contemporary immigration, we are forced to conclude that the population with precarious status will continue to grow. This may push the issue away from the nearly exclusive domain of activists and some service providers, toward the centre of public discussion.

Another point that emerged from our analysis is that precarious status and illegality are gendered and racialized processes. Although we have not made this a central focus in this paper, it is safe to say that, to the extent that specific pathways to entry and subsequent loss of status are gendered, women and men will be disproportionately affected by precarious status and illegality. For example, women are more vulnerable to sponsorship breakdown. Similarly, the prevalence of women in the Live-In Care Worker's program (Bakan and Stasiulis 1997), men in the Seasonal Agricultural Workers program (Basok 2002), and men and women under different types of humanitarian admissions (Boyd 1994) would suggest that precarious status associated with these entrance statuses would be gendered. Moreover, to the extent that source countries from the global south are over-represented among (temporary) entrance categories, we can add that racialized minorities are more vulnerable to precarious status and illegality. This would be consistent with research on economic and social inequality Canada (Galabuzi 2006) and on policy barriers to immigrant settlement (Wayland 2006).

Our discussion about the relationship between precarious status and access to services does more than draw attention to the vulnerability of people in this situation. It also challenges scholars, advocates, and the public to consider the kind of society and model of citizenship individuals and communities are in the ongoing process of building and negotiating. People with precarious immigration status are, by definition, not citizens and, therefore, are not entitled to citizenship rights. However, their lack of social, civil, political, and other citizenship means that legal status is becoming a more important dimension of social exclusion and inequality in Canada. This raises numerous questions and challenges. One question is how Canadians want to deal with a US-style underclass defined by legal status and labour-market vulnerability. Another involves examining 
how it is possible for legal status to become an important dimension of stratification with virtually no public recognition or discussion of the process. One of the challenges is that, in addition to considering the impacts and intersections of racialization, class, and gender on wellbeing, Canadian researchers need to include immigrant legal status (and not simply foreign birth or legal status upon entry) as a key variable in their investigations. Another challenge, of course, will continue to be the absence of systematic data on the topic.

How can researchers take up the challenge of studying legal status through empirical research, and not only as we have done here, through an analysis of policies and service access? In other words, how does one complement theoretical discussions with systematic empirical research? Perhaps the campaigns and networks formed by people with precarious status, in cooperation with their advocates and activists (for example, Education Rights Task Force and the "Don't Ask, Don't Tell" campaign) can contribute to expanding access to services and improving police work, as well as developing alliances to support the collection of good data. Such a strategy also must involve moving the issues surrounding precarious status from the margins of activist campaigns to the very centre of public debate.

\section{CONCLUSIONS}

This paper presented an analysis of the institutionalized production of precarious legal status in Canada. Canadian immigration policy allows for the entrance of various categories of immigrants, refugees, and temporary workers. Once in Canada, people may move out of relatively secure, but largely temporary, statuses to less secure statuses, including illegality. Building on recent work on the legal production of illegality and non-dichotomous approaches to immigrant legal status, we analyzed pathways out of legal status. While temporary residents (temporary workers, students, visitors, and refugee claimants) are particularly vulnerable to losing status, sponsorship breakdown may also lead some applicants for permanent residence, particularly women, to lose status. Given that some temporary entrance categories select on the basis of gender and are over-represented by people from the global south, it is likely that pathways to precarious status are gendered, and racialized minorities are more vulnerable to precarious status and illegality.

In addition to examining pathways out of legality, we also discussed the relationship between immigrant legal status and access to public services. Understanding both of these processes shows that binary conceptions of legal status do not reflect the Canadian policy context, nor do tri-partite approaches that add an intermediary status somewhere between legal and illegal. We have proposed the use of the term "precarious status" to capture the multiple forms of irregular status and illegality produced in Canada. Our discussion pointed to the importance of considering the following factors and processes in order to contextualize the production of precarious status and illegality: location/geography, immigration and refugee policy, main modes of legal and unauthorized entry, pathways to loss of status, and access to and provision of services to people with precarious status.

Our discussion highlighted five conclusions about precarious status in Canada. First, Canadian immigration policy does generate various forms of precarious immigration status, 
including illegality. Second, precarious status is accompanied by precarious access to public services. Third, the production of precarious status and illegality is a gendered and racialized process, something we do not address in depth, but which calls for further analysis. Fourth, precarious legal status and illegality have implications for citizenship, stratification and social exclusion in Canada. Fifth, trends in immigration and refugee policy indicate that the population with precarious status is likely to grow. We conclude by noting that, for people with precarious status, identifying various forms of precarious status may be less relevant than the overall precariousness of their everyday lives. However, for scholars, activists, agencies, and policymakers, analyzing the production of precariousness in a specific national context can contribute to the theorization of immigration status as a critical dimension of social exclusion, and to generating relevant and accurate knowledge on the topic. 
Page 32

\section{REFERENCES}

Aleinikoff, Alexander T. 1997. "The Tightening Circle of Membership," in Juan F. Perea (ed.) Immigrants Out! The New Nativism and the Anti-Immigrant Impulse in the United States, New York: New York University Press, 324-32.

Arat-Koc, Sedef. 1997. "From 'Mothers of the Nation' to Migrant Workers," in Abigail Bakan and Daiva Stasiulis (eds.) Not One of the Family: Foreign Domestic Workers in Canada. Toronto: University of Toronto Press, 53-79.

Bakan, Abigail and Stasiulis, Daiva. 1997. Not One of the Family: Foreign Domestic Workers in Canada. Toronto: University of Toronto Press.

Bashi, Vilna. 2004. "Globalized Anti-Blackness: Transnationalizing Western Immigration Law, Policy, and Practice.” Ethnic and Racial Studies 27 (4), 584-606.

Basok, Tanya. 2002. Tortillas and Tomatoes: Transmigrant Mexican Harvesters in Canada. Montreal and Kingston: McGill-Queen's University Press.

Basok, Tanya. 2004. "Post-national citizenship, social exclusion and migrants rights: Mexican seasonal workers in Canada." Citizenship Studies 8 (1), 47-64.

Basok, Tanya and Simmons, Alan. 1993. "A Review of the Politics of Canadian Refugee Selection," in Vaughan Robinson (ed.) The International Refugee Crisis: British and Canadian Responses. Hampshire: Macmillan and Refugee Studies Programme, Oxford University, 135-57.

Berinstein, Carolina; McDonald, Jean; Nyers, Peter; Wright, Cynthai; Sahar Zerehi, Sima. 2006. "Access Not Fear: Non-Status Immigrants and City Services Preliminary Report." (February.) Toronto. Accessed from:

http://www.socsci.mcmaster.ca/polisci/emplibrary/Access $\% 20$ Not $\% 20$ Fear $\% 20$ Report $\% 20$ (Feb \%202006).pdf

Bernhard, Judith; Goldring, Luin; Young, Julie; Wilson, Beth; and Berinstein, Carolina. 2008. "Living with Precarious Legal Status in Canada: Implications for the Wellbeing of Children and Families." Refuge 24 (2), forthcoming.

Bloemraad, Irene. 2006. Becoming a Citizen: Incorporating Immigrants and Refugees in the United States and Canada. Berkeley: University of California Press.

Boyd, Monica. 1994. "Gender Concealed, Gender Revealed: The Demography of Canada's Refugee Flows," in Proceedings from Conference on Gender Issues and Refugees: Development Implications. Toronto: Center for Refugee Studies, York University (May 1993).

Brubaker, Rogers. 1990. "Immigration, Citizenship, and the Nation-State in France and Germany: A Comparative Historical Analysis.” International Sociology 5, 379-407. 
Calavita, Kitty. 1998. "Immigration, Law and Marginalization in a Global Economy: Notes from Spain." Law and Society Review 32 (3), 529-526.

Carty, Linda and Brand, Dionne. 1993. "“Visible Minority' Women: A Creation of the Canadian State," in Himani Bannerji (ed.), Returning the Gaze: Essays on Racism, Feminism and Politics. Toronto: Sister Vision Press, 207-22.

Canadian Council for Refugees (CCR). 2002. State of Refugees in Canada. Retrieved 25August 2005 from http://www.web.net/\%7Eccr/state.html

Canadian Council for Refugees. n.d. Immigration to Canada: 1979-2004. Retrieved 25 August 2005 from http://www.web.net/ ccr/immstats.html

Canadian Council for Refugees. 2004. Immigration and Refugee Board Refugee Protection Division, Statistics 2004. Retrieved 1 March 2006 from http://www.web.net/ ccr/irb2004stats.html

Canadian Council for Refugees. 2006a. "Immigration and Refugee Board Statistics for 2005." Email sent to CCR list, 9 February.

Canadian Council for Refugees. 2006b. "Refugee Appeal Division Backgrounder, and FAQ" Ottawa: CCR (December). Retrieved 8 October 2007 from:

http://www.ccrweb.ca/RADpage/RADpage.htm

Canadian Council for Refugees. 2007. "Immigration and Refugee Board Statistics for 2006." Email sent to CCR list, 13 March.

Castles, Stephen and Miller, Mark J. 1993. The Age of Migration, $3^{\text {rd }}$ ed.. New York: The Guilford Press.

CIA. 2007. The World Fact Book. Retrieved 1 September 2007 from: https://www.cia.gov/library/publications/the-world-factbook/countrylisting.html

CBC. 2005. "Refugee claims down 40\% in deal's wake." CBC News. 27 July 2005. Retrieved 25 August 2005 from:

http://www.cbc.ca/story/canada/national/2005/07/27/refugee-claims050727.html.

CIC 2001. "Interim Federal Health Program. Information Handbook for Healthcare Providers." Edmonton: FAS Benefit Administrators. Retrieved 1 March 2006 from: http://www.fasadmin.com/images/pdf/ifh_information_handbook.pdf

CIC 2002a. "Length of Time You Must Support a Sponsored Relative or Family Member." Retrieved 1 March 2006 from: http://www.cic.gc.ca/english/sponsor/support.html.

CIC 2002b. "The Live-in Caregiver Program." Retrieved 1 March 2006 from: http://www.gic.gc.ca/english/pub/caregiver/caregiver-1.html. 
Page 34

CIC 2003. "Studying in Canada." Retrieved 1 March 2006 from:

http://www.gic.gc.ca/english/study.

CIC 2004a. "Facts and Figures 2004. Immigration Overview: Permanent and Temporary

Residents." http://www.cic.gc.ca/english/pub/facts2004/overview/index.html

CIC 2004b. "Facts and Figures 2004. Immigration Overview: Permanent Residents." http://www.cic.gc.ca/english/pub/facts2004/permanent/

CIC 2004c. "Facts and Figures 2004. Immigration Overview: Temporary Residents." http://www.cic.gc.ca/english/pub/facts2004/temporary/

CIC 2004d. "Facts and Figures 2004. Immigration Overview: Temporary Residents." http://www.cic.gc.ca/english/pub/facts2004/temporary/3.html

CIC 2005. "Working Temporarily in Canada." Retrieved 1 March 2006 from: http://www.cic.gc.ca/english/work/index.html.

CIC n.d. The Interim Federal Health Program. Retrieved 25 August 2005 from: http://www.cic.gc.ca/ref-protection/english/infocentre/settlement-etablissement/commprof/appendix_i.htm.

CIC. 2006a. "Facts and Figures 2006. Immigration Overview: Permanent and Temporary Residents." Retrieved 1 September 2007 from:

http://www.cic.gc.ca/english/resources/statistics/menu-fact.asp

CIC. 2006b. "Annual Report to Parliament on Immigration, 2006."

http://www.cic.gc.ca/ENGLISH/resources/publications/annual-report2006/section3.asp

Cohen, Rina. 1994. "Importing Maids: Racialization of Canadian Immigration Policies For Recruiting Domestics During the 20th Century." The Social Science Journal 1994, 17-28.

Community Social Planning Council of Toronto (CSPC-T). 2007. Toronto Community Resource Guide for Non-Status Immigrants. Toronto: CSPC-T and Davenport Perth Neighbourhood Centre (in partnership with Don't Ask, Don't Tell Campaign). Available at:

http://www.socialplanningtoronto.org/Index3.htm

Construction Recruitment External Workers Services (CREWS) n.d. Retrieved 1 March 2006 from: http://www.constructionworkers.ca.

Corelli, Rae. 1996. "Manhunt: police have nabbed 3,600 alien fugitives - with 9,000 on the lam." Macleans 109 (33), 36.

De Genova, Nicholas P. 2002. "Migrant 'Illegality' and Deportability in Everyday Life." Annual Review of Anthropology 31, 419-47. 
De Genova, Nicholas P. 2005. Working the Boundaries: Race, Space, and "Illegality" in Mexican Chicago. Durham, NC: Duke University Press.

Dench, Janet n.d. "A Hundred Years of Immigration to Canada 1900-1999: A Chronology Focusing on Refugees and Discrimination." Retrieved 25 August 2006 from:

http://www.web.net/\%7Eccr/history.html

Dench, Janet. 2005. E-mail communication, 25 July 2005.

FCJ Refugee Centre 2005. "Refugee Protection Claim Process." Retrieved March 1, 2006 from: http://www.fcjsisters.ca/RefugeeCentre/claimprocess.htm.

Freeze, C. and Jimenez, Marina. 2004. "Stripper Put Ottawa Story at Centre Stage." Globe and Mail. 27 November. Retrieved 25 August 2005 from:

http://www.theglobeandmail.com/servlet/story/RTGAM.20041126.wstrip27/BNStory/Front/.

Fudge, Judy and Owens, Rosemary J. 2006. Precarious Work, Women and the New Economy: The Challenge to Legal Norms. Oxford: Hart Publishing.

Galabuzi, Grace-Edward. 2006. Canada's Economic Apartheid: The Social Exclusion of Racialized Groups in the New Century. Toronto: Canadian Scholars's Press.

Guang, Tian and Jin, Lu. 1996. "Struggling for Legal Status: Mainland Chinese Mobilization in Canada." Refuge 15, 26-32.

Goldring, Luin. 2006. "Latin American Transnationalism in Canada: Does It Exist, What Forms Does It Take and Where Is It Going?" in Victor Satzewich and Lloyd Wong (eds.) Transnational Identities and Practices in Canada. Vancouver: University of British Columbia Press, 180-201.

Goldring, Luin. 2005. "Más allá de las remesas y clubes en el desarrollo: La seducción, posibilidades y limitantes de la ciudadanía neoliberal." Presented at the conference on Problemas y Desafios de la Migración y el Desarrollo en América (CRIM-RIMD-CERLAC). Cuernavaca, Morelos, Mexico. (April 7-9).

Hagan, Jacqueline Maria. 1994. Deciding to be Legal: A Maya Community in Houston. Philadelphia: Temple University Press.

Hammar, Thomas. 1990. Democracy and the Nation State: Aliens, Denizens and Citizens in a World of International Migration. Brookfield, VT: Gower Publishing Co.

Heyman, Josiah M. 2001. "Class and Classification at the US-Mexico border." Human Organization $60,128-140$.

Hier, Sean P. and Greenberg. Joshua. 2002. "Constructing a Discursive Crisis: Risk, Problematization and Illegal Chinese in Canada." Ethnic and Racial Studies 25 (3), 490-513. 
Page 36

Human Resources and Social Development Canada (HRSDC). 2006. "Hiring Temporary Foreign Workers for Occupations under Pressure." Ottawa: Human Resources and Social Development Canada.

Jimenez, Marina. 2003. “200,000 Illegal Immigrants Toiling in Canada’s Underground Economy.” Globe and Mail. 15 November.

Jimenez, Marina. 2006. “Ottawa Rules Out Amnesty for 200,000 Illegal Workers.” Globe and Mail. 27 October.

Justicia for Migrant Workers 2005. "Seasonal Agricultural Workers Program.” Retrieved 1 March 2006 from: http://www.justicia4migrantworkers.org/saw.htm.

Kelly, Philip. 2006. Filipinos in Canada: Economic Dimensions of Immigration and Settlement, Working Paper No. 48. Toronto: Joint Centre of Excellence for Research on Immigration and Settlement.

Khandor, Erika; McDonald, Jean; Nyers, Peter; and Wright, Cynthia. 2004. The Regularization of Non-Status Immigrants in Canada 1960-2004: Past Policies, Current Perspectives, Active Campaigns. Retrieved 28 August 2005 from:

http://www.socialplanningtoronto.org/Research\%20\&\%20Policy\%20Updates/Regularization_bo oklet.pdf.

Koehl, Albert. 2007. "Unlocking the School Door: Immigrant Status and the Right to Learn." Education Canada 47, 58-61.

Koser, Khalid. 2001. "New Approaches to Asylum.” International Migration 39, 85-100.

Kymlicka, Will. 1995. Multicultural Citizenship. New York: Oxford University Press.

Labelle, Micheline and Salée, Daniel. 2001. "Immigrant and Minority Representations of Citizenship in Quebec," in T. Alexander Aleinikoff and Douglas Klusmeyer (eds). Citizenship Today: Global Perspectives and Practices. Washington, DC: Carnegie Endowment for International Peace, 278-315.

Lacroix, Marie. 2004. "Canadian Refugee Policy and the Social Construction of the Refugee Claimant: Understanding Refugeeness.” Journal of Refugee Studies 17, 147-166.

Landolt, Patricia; Autler, Lilain; and Baires, Sonia. 1999. "From Hermano Lejano to Hermano Mayor: The Dialectics of Salvadoran Transnationalism." Ethnic and Racial Studies 22, 290-315.

Latin American Coalition to End Violence Against Women and Children (LACEV). 2002. Coming to Dance, Striving to Survive: A Study on Latin American Migrant Exotic Dancers. Toronto: LACEV. 
Latin American Coalition to End Violence Against Women and Children (LACEV). 2000. No (Wo)Man's Land. Toronto: LACEV.

Lister, Ruth. 1997. "Citizenship: Towards a Feminist Synthesis." Feminist Review 57, 28-48.

Lowell, Lindsay B.; de la Garza, Rodolfo; and Hogg, Mike. 2000. "Remittances, US Latino Communities, and Development in Latin American Countries." Migration World Magazine 28, 1317.

Lowry, Michelle. 2002. "Creating Human Insecurity: The National Security Focus in Canada's Immigration System.” Refuge 21 (1), 28-39.

Lowry, Michelle and Nyers, Peters. 2003. “'No One Is Illegal': The Fight for Refugee and Migrant Rights in Canada." Refuge 21 (3), 66-72.

Marshall, T. H. and Bottomore, T. B. 1992. Citizenship and Social Class. London and Concord, MA: Pluto Press.

Massey, Douglas; Alarcón, Rafael; Durand, Jorge; and González, Humberto. 1987. Return to Aztlán: The Social Process Of International Migration from Western Mexico. Berkeley: University of California Press.

Menjívar, Cecilia. 2000. Fragmented Ties: Salvadoran Immigrant Networks in America. Berkeley: University of California Press.

Menjívar, Cecilia. 2006. "Liminal Legality: Salvadoran and Guatemalan Immigrants' Lives in the United States." American Journal of Sociology 111 (4), 999-1037.

Mickleburgh, Rod. 2000. "Canada deports Chinese Migrants en Masse: 90 Boat People Depart under Heavy Security." Globe and Mail, A1.

Migration Policy Institute. 2004. "Comparing Migrant Stock: The Five Largest Foreign-Born Groups in Australia, Canada, and the United States." Washington, D.C.: MPI. Retrieved from: http://www.migrationinformation.org/DataTools/migrant_stock_groups.cfm

Mines, Richard. 1981. Developing a Community Tradition of Migration to the United States: A Field Study in Rural Zacatecas, Mexico, and California Settlement Areas. La Jolla, CA: Program in United States-Mexican Studies, University of California San Diego.

Mountz, Alison. 2004. "Embodying the Nation-State: Canada's Response to Human Smuggling." Political Geography 23 (3), 323-345.

Nef, Jorge. 1991. "The Politics of Refugee Generation in Latin America." in Howard Adelman (ed.) Refugee Policy: Canada and the United States. Toronto: York Lanes Press Ltd. 
Page 38

Omidvar, Ratna and Richmond, Ted. 2003. "Immigrant Settlement and Social Inclusion in Canada." Toronto: Laidlaw Foundation. Working Paper Series. Available at: http://www.laidlawfdn.org/files/children/richmond.pdf

Ornstein, Michael. 2006. Ethno-racial Groups in Toronto, 1996-2001: A Demographic and SocioEconomic Profile. Toronto: Institute for Social Research, York University. Available at: http://www.isr.yorku.ca/download/Ornstein--Ethno-Racial_Groups_in_Toronto_1971-2001.pdf

Oxman-Martinez, Jacqueline; Hanley, Jill; Lach, Lucynda; Khanlou, Nazilla; Weerasinge, Swarna; and Agnew, Vijay. 2005. "Intersection of Canadian Policy Parameters Affecting Women with Precarious Immigration Status: A Baseline for Understanding Barriers to Health." Journal of Immigrant Health 7 (4), 247-258.

Papademetriou, Demetrios. 2005. "The Global Struggle with Illegal Migration: No end in sight." Washington, D.C.: Migration Information Source. (1 September). Available at: http://www.migrationinformation.org/Feature/display.cfm?ID=336

Parkdale Community Legal Sesrvices (PCLS). 1998. Living Without Status. Final Report: Recommendations. Conference on "Living Without Status: Human Rights Underground." Toronto: Parkdale Community Legal Services. 2-3 March.

Passel, Jeffrey. 2002. "New Estimates of the Undocumented Population in the United States." in Migration Policy Institute (ed.) Migration Information Source. Washington, DC: Migration Policy Institute.

Preibisch, Kerry. 2004. "Migrant Agricultural Workers and Processes of Social Inclusion in Rural Canada: Encuentros and Desencuentros." Canadian Journal of Latin American and Caribbean Studies 29 (57-58), 203-239.

Portes, Alejandro and Rumbaut, Rubén G. 1996. Immigrant America: A Portrait. Berkeley, CA: University of California Press.

Powers, Mary G.; Percy Kraly, Ellen; and Seltzer, William. 2004. "IRCA: Lessons of the Last US Legalization Program." Migration Information Source. Washington, DC: Migration Policy Institute. (1 July). Available at: http://www.migrationinformation.org/Feature/display.cfm?ID=233

Raymont, Peter and Tracey, Lindalee. 2002. "The Undefended Border." Film/Video. White Pine Pictures.

Reitz, Jeffrey G. 1998. Warmth of the Welcome: The Social Causes of Economic Success for Immigrants in Different Nations and Cities. Boulder, CO: Westview Press.

Reitz, Jeffrey. 2005. “Tapping Immigrants' Skills: New Directions for Canadian Immigration Policy in the Knowledge Economy." IRPP Choices 11 (1), 2-18. Available at: http://www.utoronto.ca/ethnicstudies/reitzchoices.pdf 
Page 39

Richmond, Anthony H. 1994. Global Apartheid: Refugees, Racism and the New World Order. Don Mills, ON: Oxford University Press Canada.

Robertson, Grant. 2005. "Canada Has No Handle on Illegal Immigrant Workers." Edmonton Journal, 30 May, A5.

Roffey, Rhonda. 2007. Personal communication. Executive Director of Women's Habitat, Toronto. 17 October.

San Martin, Ruth Magaly. 2004. "Unwanted in Paradise: Undocumented Migrant Women Sex Workers in Toronto." in R. B. Folson(ed.), Calculated kindness: Global Restructuring, Immigration and Settlement in Canada. Halifax: Fernwood Publishing, 71-82.

Sharma, Nandita. 2001. “On Being Not Canadian: The Social Organization of 'Migrant Workers' in Canada." Canadian Review of Sociology and Anthropology 38 (4), 415-40.

Sharma, Nandita. 2002. "Immigrant and Migrant Workers in Canada: Labour Movements, Racism and the Expansion of Globalization.” Canadian Woman Studies 21 (4), 18-26.

Simich, Laura. 2006. "Hidden Meanings of Health Security: Migration Experiences and Systemic Barriers to Mental Wellbeing among Non-Status Migrants in Canada." International Journal of Migration, Health and Social Care 2 (3/4), 16-27.

Simich, Laura; Wu, Fei; and Nerad, Sonja. 2007. "Status and Health Security: An Exploratory Study among Irregular Immigrants in Toronto.” Canadian Journal of Public Health 98 (5), 369-73.

Singh, Jaggi. 2006. "Immigrant Rights Organizations across Canada Demand a Moratorium on Deportations, and the Regularization of 500,000 Migrants." Solidarity Across Borders. (1 May). Available at: http://solidarityacrossborders.org/en/node/152

Simmons, Alan. 1998. "Racism and Immigration Policy," in Vic Satzewich (ed.) Racism and Social Inequality in Canada. Toronto: Thompson Educational Publishing, 87-114.

Stasiulis, Daiva and Bakan, Abigail. 1997. "Negotiating Citizenship: The Case of Foreign Domestic Workers in Canada." Feminist Review 57, 112-139.

Stasiulis, Daiva K. and Bakan, Abigail B. 2003. Negotiating Citizenship: Migrant Women in Canada and the Global System. Houndmills, Basingstoke, Hampshire ; New York: Palgrave Macmillan.

STATUS Campaign to Regularize Non-Status Immigrants. 2003. Definitions. Accessed 22 November 2003 from: http://www.ocasi.org/status/docs_definitions.shtml.

Stoffman, Daniel. 2002. Who Gets In: What's Wrong with Canada's Immigration Program-And How to Fix It. Toronto: Macfarlane Walter \& Ross. 
Page 40

Thomas, Robert J. 1981. "The Social Organization of Industrial Agriculture." The Insurgent Sociologist 10 (3), 5-20.

Van Hook, Jennifer; Bean, Frank D.; and Passel, Jeffrey. 2005. "Unauthorized Migrants Living in the United States: A Mid-Decade Portrait." Washington, D.C. Migration Policy Institute. Migration Information Source. (1 September). Available at:

http://www.migrationinformation.org/Feature/display.cfm?id=329

Vickery, Claude. 2004. The fifth estate: Run for Your Life. Canada: Canadian Broadcasting Corporation.

Vosko, Leah. F. 2006. Precarious Employment: Understanding Labour Market Insecurity in Canada. Montreal and Kingston: McGill-Queen's University Press.

Waldie, Paul; Freeman, Alan; and Perkins, Tara. 2007. "Windsor Braces for Refugee Tide." Globe and Mail.

Waldman, Lorne. 2006. "We're as Guilty as the Illegal Immigrants.” Globe and Mail.

Warren, Robert and Passel, Jeffrey S. 1987. "A Count of the Uncountable: Estimates of Undocumented Aliens Counted in the 1980 United States Census." Demography 24, 375-393.

Wayland, Sarah. 2006. Unsettled: Legal and Policy Barriers for Newcomers to Canada. Ottawa: Community Foundations of Canada and Law Commission of Canada. Available at: http://www.cfcfcc.ca/whats_new_view.cfm?id=832

Wright, Cynthia. 2003. "Moments of Emergence: Organizing by and with Undocumented and NonCitizen People in Canada after September 11.” Refuge 21 (3), 5-15.

Young, Julie. 2005. “'This is My Life:' Questions of Agency and Belonging among Youth Living with Less than Full Status," npublished Master's Major Research Paper. Program in Immigration and Settlement Studies. Toronto: Ryerson University.EN.REFLIST. 


\section{CERIS - The Ontario Metropolis Centre}

CERIS - The Ontario Metropolis Centre is one of five Canadian Metropolis centres dedicated to ensuring that scientific expertise contributes to the improvement of migration and diversity policy.

CERIS - The Ontario Metropolis Centre is a collaboration of Ryerson University, York University, and the University of Toronto, as well as the Ontario Council of Agencies Serving Immigrants, the United

Way of Greater Toronto, and the Community Social Planning Council of Toronto.

CERIS wishes to acknowledge receipt of financial grants from the Social Sciences and Humanities

Research Council of Canada and Citizenship and Immigration Canada and the data provided by Statistics

Canada.

CERIS appreciates the support of the Departments and Agencies

participating in the Metropolis Project:

Citizenship and Immigration Canada

Social Sciences and Humanities Research Council of Canada

Department of Canadian Heritage

Canada Mortgage and Housing Corporation

Human Resources and Social Development Canada

Public Health Agency of Canada

Public Safety Canada

Canada Border Services Agency

Justice Canada

Royal Canadian Mounted Police

Atlantic Canada Opportunities Agency (ACOA)

Canada Economic Development for Quebec Regions (CEDQ)

Federal Economic Development Initiative for North Ontario (FedNor)

The Rural and Cooperatives Secretariats of

Agriculture and Agri-Food Canada

Statistics Canada

For more information about CERIS contact:

CERIS - The Ontario Metropolis Centre

246 Bloor Street West, $7^{\text {th }}$ Floor, Toronto, Ontario, Canada M5S 1V4

Telephone: (416) 946-3110 Facsimile: (416) 971-3094

http://ceris.metropolis.net 


\section{The Metropolis Project}

Launched in 1996, the Metropolis Project strives to improve policies for managing migration and diversity by focusing scholarly attention on critical issues. All project initiatives involve policymakers, researchers, and members of non-governmental organizations.

Metropolis Project goals are to:

- $\quad$ Enhance academic research capacity;

- $\quad$ Focus academic research on critical policy issues and policy options;

- Develop ways to facilitate the use of research in decision-making.

The Canadian and international components of the Metropolis Project encourage and facilitate communication between interested stakeholders at the annual national and international conferences and at topical workshops, seminars, and roundtables organized by project members.

For more information about the Metropolis Project

visit the Metropolis web sites at:

http://canada.metropolis.net

http://international.metropolis.net

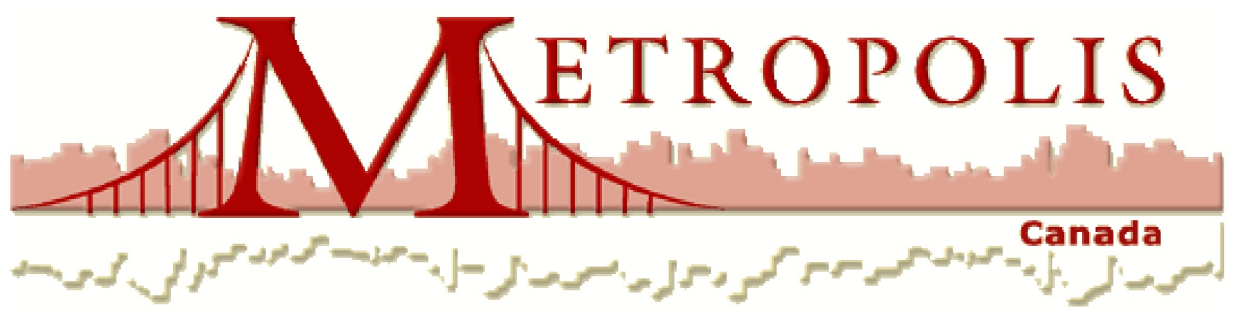

